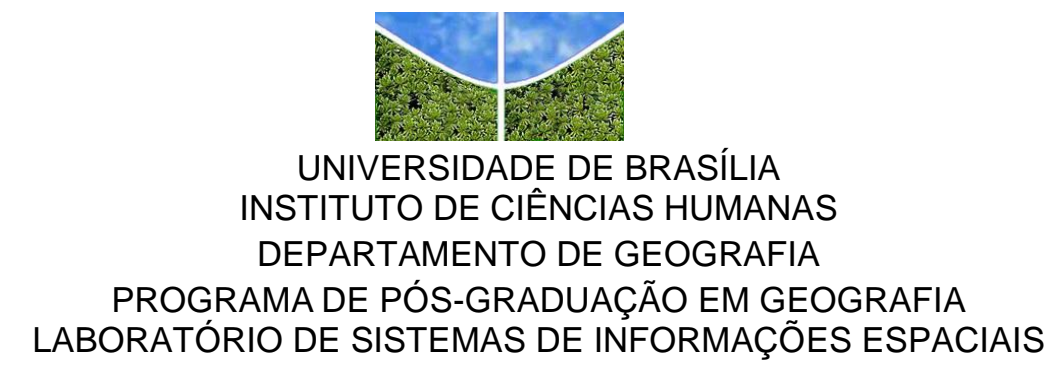

ANÁLISE DAS MÉTRICAS DOS FRAGMENTOS FLORESTAIS E DOS PADRÕES ESPACIAIS MORFOLÓGICOS A PARTIR DE RESTITUIÇÃO FOTOGRAMÉTRICA DE FOTOGRAFIAS AÉREAS DIGITAIS

\author{
Wilma Tavares Braga \\ Orientador: Prof. Dr. Renato Fontes Guimarães \\ Co-orientador: Prof. Dr. Osmar Abílio de Carvalho Júnior \\ DISSERTAÇÃO DE MESTRADO
}

Brasília- DF

JULHO / 2016 


\author{
UNIVERSIDADE DE BRASÍLIA \\ INSTITUTO DE CIÊNCIAS HUMANAS \\ DEPARTAMENTO DE GEOGRAFIA \\ PROGRAMA DE PÓS-GRADUAÇÃO EM GEOGRAFIA \\ LABORATÓRIO DE SISTEMAS DE INFORMAÇÕES ESPACIAIS
}

\title{
ANÁLISE DAS MÉTRICAS DOS FRAGMENTOS FLORESTAIS E DOS PADRÕES ESPACIAIS MORFOLÓGICOS A PARTIR DE RESTITUIÇÃO FOTOGRAMÉTRICA DE FOTOGRAFIAS AÉREAS DIGITAIS
}

\author{
Wilma Tavares Braga
}

Dissertação de Mestrado submetida ao Departamento de Geografia da Universidade de Brasília, como parte dos requisitos necessários para obtenção do Grau de Mestre em Geografia, área de concentração Gestão Ambiental e Territorial e linha de pesquisa Geoprocessamento.

Aprovado por:

Prof. Dr. Renato Fontes Guimarães

Universidade de Brasília - Departamento de Geografia

Orientador

Prof. Dr. Osmar Abílio de Carvalho Júnior

Universidade de Brasília - Departamento de Geografia

Co-orientador

Prof. Dra. Potira Meirelles Hermuche

Universidade de Brasília - Departamento de Geografia

Examinador Interno

Prof. Dr. Éder de Souza Martins

EMBRAPA/DF Examinador Externo

Brasília- DF, 1ํ de julho de 2016. 
FICHA CATALOGRÁFICA

BRAGA, WILMA TAVARES

Análise das Métricas dos Fragmentos Florestais e dos Padrões Morfológicos a partir de Restituição Fotogramétrica de Fotografias Aéreas Digitais. 40p. (UnB-IH-GEA-LSIE, Mestrado, Gestão Ambiental e Territorial, 2016).

Dissertação de Mestrado - Universidade de Brasília. Departamento de Geografia

1 - fragmentação da paisagem, $\quad 2$-mata atlântica,

3 - Patch analyst, $\quad 4$-padrões espaciais morfológicos.

I. UnB-IH-GEA-LSIE

\section{REFERÊNCIA BIBLIOGRÁFICA}

BRAGA, W. T. Análise das Métricas dos Fragmentos Florestais e dos Padrões Morfológicos a partir de Restituição Fotogramétrica de Fotografias Aéreas Digitais. 2016. 40 f. Dissertação (Mestrado em Geografia) - Instituto de Ciências Humanas, Universidade de Brasília, Distrito Federal, 2016.

\section{CESSÃO DE DIREITOS}

Nome do autor: Wilma Tavares Braga

Título da dissertação: Análise das Métricas dos Fragmentos Florestais e dos Padrões Morfológicos a partir de Restituição Fotogramétrica de Fotografias Aéreas Digitais.

Grau/ano: Mestre/2016

É cedida à Universidade de Brasília permissão para reproduzir cópias desta dissertação e emprestar ou vender tais cópias somente para propósitos acadêmicos e científicos. O autor reserva outros direitos de publicação e nenhuma parte desta dissertação de mestrado pode ser reproduzida sem a autorização por escrito do autor.

Wilma Tavares Braga 


\section{AGRADECIMENTOS}

Primeiramente a Deus e a Nossa Senhora, por sempre estarem presentes na minha vida, me amparando e dando forças.

À minha mãe Maria de Jesus pelo amor, carinho e paciência.

Ao meu noivo Rodrigo Cesar pelo amor, apoio, força, incentivo e companheirismo.

Ao meu filho por transformar minha vida em alegria e amor.

Ao meu professor orientador, Renato Fontes Guimarães, pelo acompanhamento, amizade, paciência e aprendizado.

Ao professor co-orientador, Osmar Abílio de Carvalho Júnior, pela contribuição, paciência, entusiasmo e boa vontade na realização deste trabalho.

Ao professor Roberto Arnaldo Trancoso Gomes pela colaboração.

Aos colegas do Laboratório de Sistemas de Informações Espaciais (LSIE) Priscila Câmara, Verônica, Natanael, Paulo, Cristiane, Miriam, Priscila Lopes e Anesmar que muito me ajudaram nessa caminhada e em especial ao Sandro e à Potira, pela amizade, disposição e contribuições ao trabalho.

A CAPES, pela bolsa de estudos concedida.

À Empresa Paulista de Planejamento Metropolitano (EMPLASA) por ter cedido os produtos cartográficos. 


\section{RESUMO}

O presente trabalho teve como objetivo realizar o mapeamento dos fragmentos florestais na Alta bacia Jacaré-Pepira, localizada no município de São Pedro - SP. A metodologia é subdivida em: (a) mapeamento dos fragmentos florestais, (b) delimitação das áreas de proteção de acordo com Lei 12.651/12, (c) obtenção das métricas de fragmentação da paisagem, (d) análise do padrão espacial morfológico. As métricas tradicionais da paisagem foram obtidas pelos programas Patch Analyst. A Análise de Padrões Espaciais Morfológicos (MSPA) foi realizada a partir da simulação de 4 cenários para a verificação da funcionalidade das Áreas de Preservação Permanente (APP), considerado 5 larguras de buffer, entre 1 e 40 metros. Os resultados obtidos mostraram que as APPs da paisagem se encontram fragmentadas e a conectividade entre elas é mínima. O método descrito evidencia a funcionalidade e importância das APPs para a paisagem.

Palavras-chave: Fragmentação da paisagem, Mata Atlântica, Patch Analyst, Análise de Padrões Espaciais Morfológicos. 


\begin{abstract}
This study aimed to carry out the mapping of forest fragments in the Upper Basin Jacaré-Pepira, located in São Pedro - SP. The methodology is subdivided into: (a) mapping of forest fragments, (b) delimitation of protected areas in accordance with Law 12,651 / 12, (c) obtaining the landscape fragmentation metrics (d) analysis of morphological spatial pattern. Traditional metrics of the landscape were obtained by Patch Analyst programs. The Spatial Pattern Analysis Morphological (MSPA) was held from 4 simulation scenarios for checking the functionality of the Permanent Preservation Areas (APP), considered 5 buffer widths between 1 and 40 meters. The results showed that the landscape PPAs are fragmented and connectivity between them is minimal. The method shows the functionality and importance of PPAs for the landscape.
\end{abstract}

Keywords: Landscape fragmentation, Atlantic forest, Patch Analyst, Morphological Spatial Pattern Analysis. 


\section{SUMÁRIO}

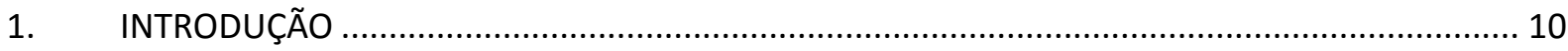

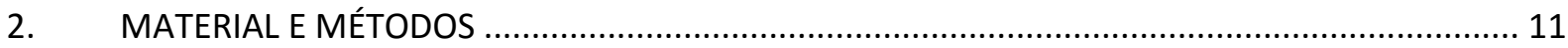

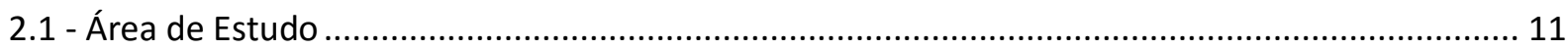

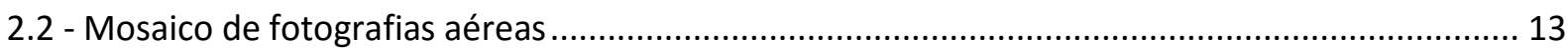

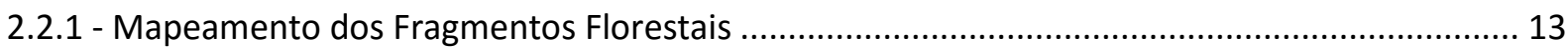

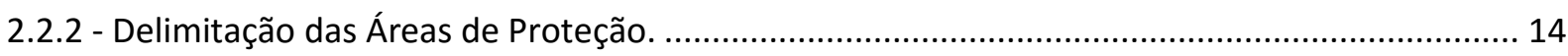

2.2.3 - Métricas de Fragmentação da Paisagem ........................................................................... 14

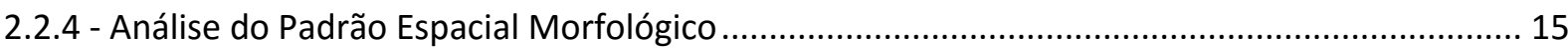

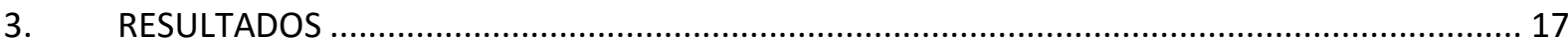

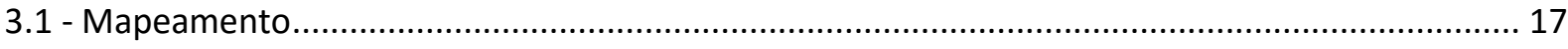

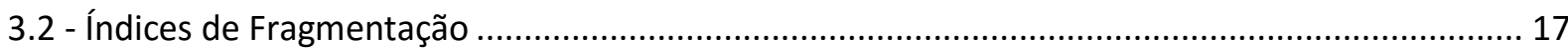

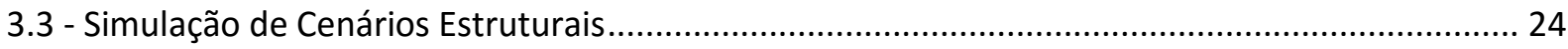

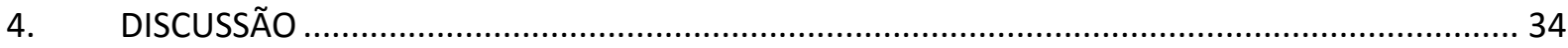

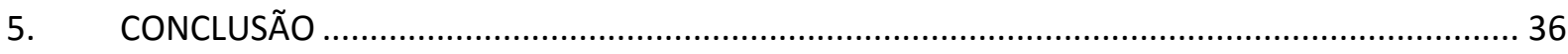

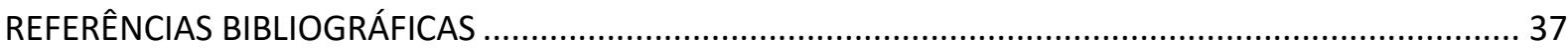




\section{LISTA DE FIGURAS}

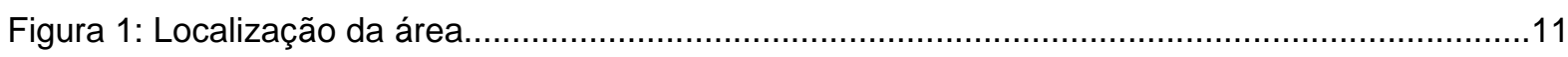

Figura 2: Mapeamento da vegetação natural e reflorestada na Alta bacia do Jacaré-Pepira..............19

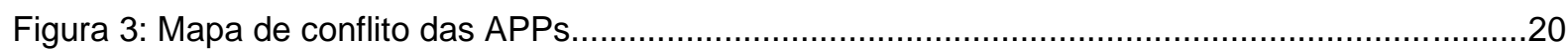

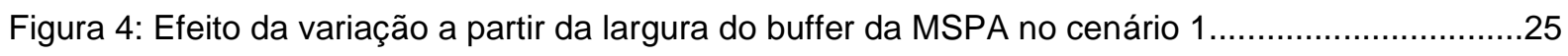

Figura 5: Efeito da variação a partir da largura do buffer da MSPA no cenário 2.............................26

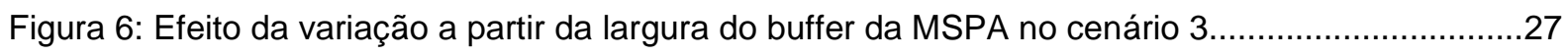

Figura 7: Efeito da variação a partir da largura do buffer da MSPA no cenário $4 \ldots \ldots \ldots \ldots \ldots \ldots \ldots \ldots \ldots . . . \ldots \ldots$

Figura 8: Resultados da MSPA da área de estudo para os 4 cenários........................................

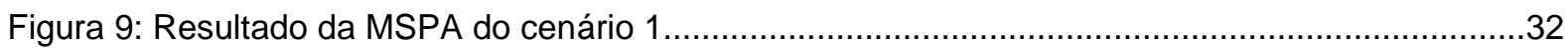

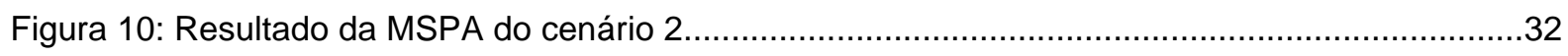

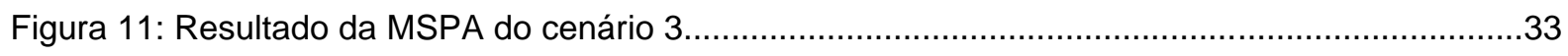

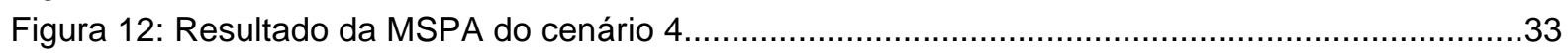




\section{LISTA DE TABELAS}

Tabela 1: Métricas do Spatial Statistics referentes à composição e configuração dos fragmentos

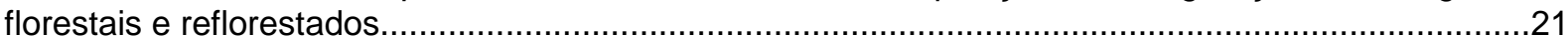
Tabela 2: Métricas do Spatial Statistics referentes ao cenário atual e ao cenário somado às

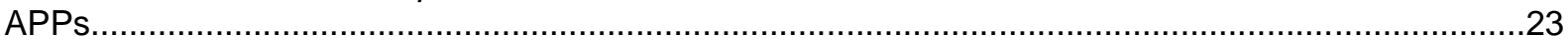

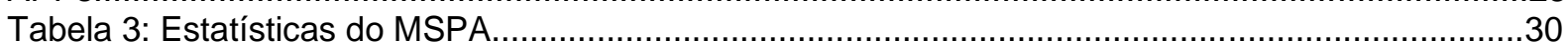




\section{INTRODUÇÃO}

A fragmentação da paisagem é o processo no qual um habitat original e contínuo é dividido em fragmentos com diferentes graus de isolamento (HERMÁNDEZ et al., 2014). A fragmentação pode ser proveniente de fatores naturais (morros, lagos, entre outros) ou antrópicos (extração florestal, queimadas, exploração agropecuária, urbanização, entre outros). Atualmente, o principal agente da fragmentação é o aumento da população global e de suas demandas, como alimentos e moradia, que intensificam o processo de conversão das paisagens naturais para antrópicas (HERMÁNDEZ et al., 2014). Quanto maior a fragmentação, menor será a área dos fragmentos e a conectividade entre eles, como também, maior será o número de fragmentos e a distância entre eles (McGARIGAL e MARKS, 1995; GUNLINCK e WAGENDORP, 2002). A fragmentação da paisagem natural acarreta prejuízos ao meio ambiente, tais como: alterações no microclima, deterioração da qualidade de vida das populações, degradação dos recursos naturais, perda de habitats naturais, biodiversidade e serviços ecossistêmicos, entre outros (VIANA, 1990; VALENTE, 2001; CERQUEIRA et al., 2003; BOGAERT et al., 2004; FOLEY et al., 2005; NETTESHEIM et al., 2010).

Os fragmentos são fontes de dados biológicos para a restauração da paisagem e conservação da fauna e da flora. Desta forma, torna-se cada vez mais importante a realização de estudos que identifiquem e avaliem o grau de fragmentação das formações vegetais que ainda existam, uma vez que a quantificação, localização espacial e definição de sua forma são condições básicas para a implantação de qualquer política preservacionista (MARQUES, 2004).

A análise da fragmentação florestal é realizada a partir de métricas, que descrevem e quantificam as características espaciais dos fragmentos. Diferentes métricas têm sido usadas para descrever os padrões espaciais a partir de produtos temáticos (Pirovani, 2010) e a capacidade de quantificar a estrutura da paisagem é o pré-requisito para o estudo da função e das alterações de uma paisagem (McGarigal e Marks, 1995). Assim, os resultados das métricas possibilitam realizar um diagnóstico de áreas fragmentadas considerando os atributos referentes à área, densidade, tamanho, variabilidade, borda e forma. Essas métricas associadas à aplicação da legislação ambiental contribuem e auxiliam na gestão da conservação desses fragmentos, determinando assim áreas de relevância para a conservação.

$O$ presente trabalho tem como objetivo geral mapear os fragmentos florestais que se encontram na Alta bacia do Jacaré-Pepira no município de São Pedro - SP.

Como objetivo específico pretende-se avaliar a funcionalidade das áreas de proteção ambiental e a importância da manutenção de corredores ecológicos a partir do cálculo das métricas dos fragmentos, da delimitação das áreas de preservação descrita na legislação, da classificação morfológica e da simulação de cenários. 


\section{MATERIAL E MÉTODOS}

\section{1 - Área de Estudo}

A área de estudo encontra-se na Alta bacia Jacaré-Pepira (Figura 1), dentro do município de São Pedro, que está localizado na porção centro-sul do Estado de São Paulo.

Ela está inserida na Bacia Hidrográfica do Rio Tietê-Jacaré definida como UGRHI-13, Unidade de Gerenciamento de Recursos Hídricos-13, de acordo com a Lei n 9.034/94, que versa sobre o Plano Estadual de Recursos Hídricos do Estado de São Paulo, que é dividida em três sub-bacias: Tietê, Jacaré-Guaçu e Jacaré-Pepira.

A sub-bacia Jacaré-Pepira estende-se por $1.411,08 \mathrm{~km}^{2}$, ocupando $8,86 \%$ da área da UGRHI-13 e abrange os municípios de São Pedro, Torrinha, Brotas, Dourados, Dois Córregos, Ribeirão Bonito e Itirapina. A principal nascente do rio está localizada na Serra de Itaqueri, próxima à divisa dos municípios São Pedro/ Itirapina/ Brotas, a uma altitude aproximada de 960 metros, e deságua no rio Tietê, no município de lbitinga, situado a aproximadamente 400 metros acima do nível médio do mar, apresentando, ao longo do seu curso um desnível de quase 500 metros (IPT, 2010).

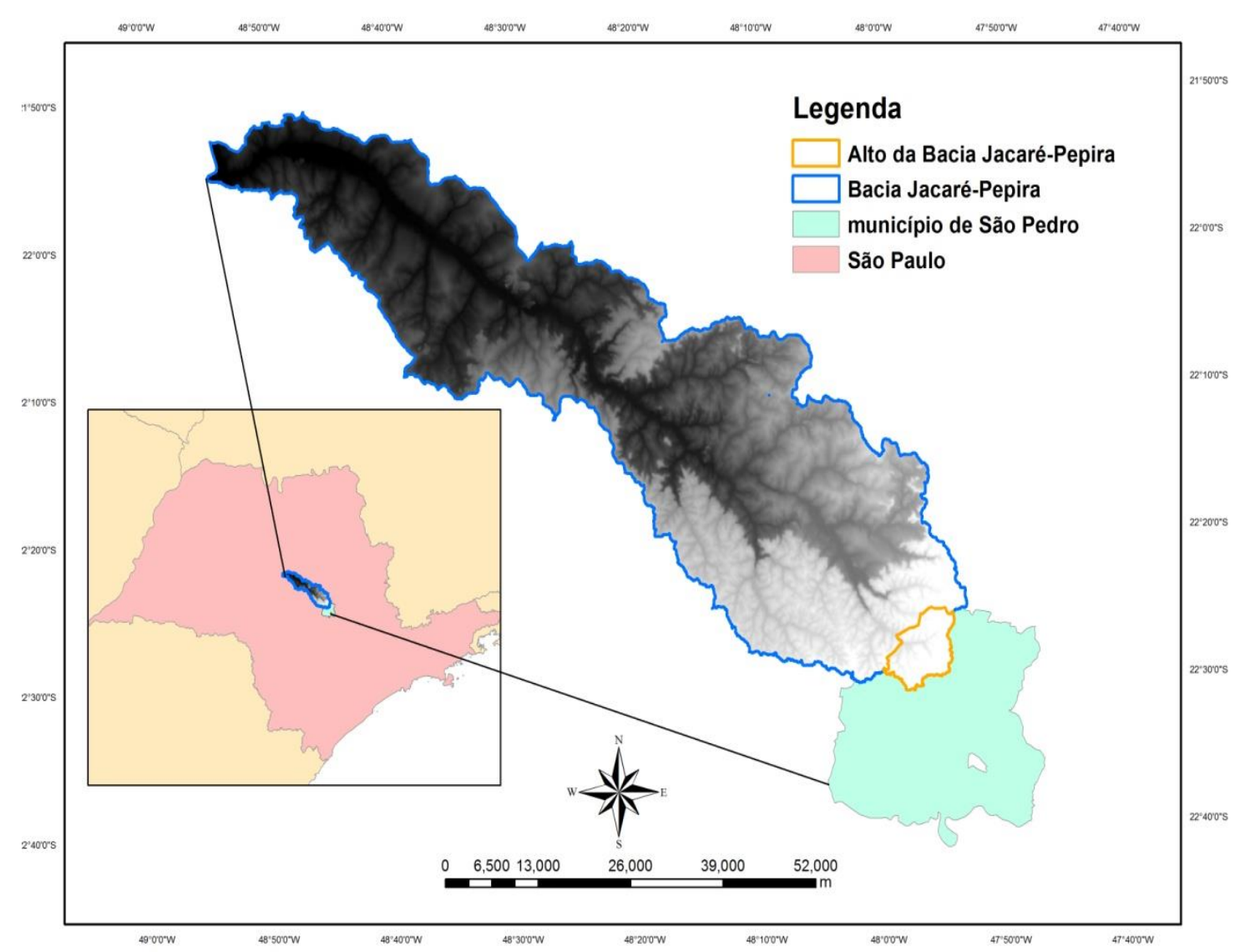

Figura 1: Localização da área de estudo. 
De acordo com a classificação de Koppen, o clima da região pode ser definido como mesotérmico úmido, caracterizado pelo clima tropical chuvoso com inverno seco e o mês mais frio com temperatura média superior a $18{ }^{\circ} \mathrm{C}$. O mês mais seco tem precipitação inferior a 60 $\mathrm{mm}$ e período chuvoso que se atrasa para o outono. Existe uma grande influência da altitude e da configuração do relevo (Serra de São Pedro) nas oscilações térmicas e pluviométricas do município (FACINCANI 1995).

O município encontra-se na borda centro leste da Bacia Sedimentar do Paraná, formada por variadas litologias que podem ser classificadas em 4 grandes domínios geológicos: rochas metamórficas e graníticas; rochas sedimentares mesozóicas e paleozóicas; rochas efusivas e corpos intrusivos básicos e coberturas sedimentares Cenozóicas. Quanto às características geológicas, apresenta terrenos pertencentes à série Passa Dois e também a presença das Formações Irati e Corumbataí (Sanchez,1971).

O município de São Pedro localiza-se na unidade geomorfológica conhecida no Estado de São Paulo por Depressão Paleozóica, também denominada de Depressão Periférica Paulista ou de Zona de Circundesnudação Periférica (AB' SABER, 1949). A Depressão Periférica Paulista divide-se três províncias: Zona do Médio Tietê, Zona do Paranapanema e Zona do Mogi Guaçu (Almeida, 1974). Nesta unidade geomorfológica, São Pedro situa-se na província Zona do Médio Tietê entre o planalto Atlântico (Planalto de Jundiaí) a leste, o planalto Ocidental Paulista (Planalto Centro Ocidental e planalto Residual de Botucatu e de São Carlos) a oeste e a Depressão de Mogi-Guaçu, ao norte (Ross \& Moroz, 1997).

São Pedro possui uma pequena extensão, inferior a $10 \%$, conhecida por Serra de São Pedro, no qual a área de estudo é limítrofe, que marca a passagem da Depressão Periférica para o Planalto Arenito-Basáltico ou Planalto Ocidental (Sanches, 1971). Esta pequena área apresenta características próprias que não condizem com nenhuma dessas unidades morfológicas, e também apresentam falhas cenozoicas refletindo nos traços gerais do relevo e da geomorfologia regional (FACINCANI, 1995).

O solo do município de São Pedro é caracterizado por uma predominância de solo do tipo: Latossolos Vermelho-Amarelos fase arenosa e algumas manchas isoladas de Latossolos Vermelho (Sanches, 1971). Essa aparência se deve a disposição natural ao desenvolvimento de processos erosivos, ligados a outras características naturais, como a morfometria do relevo, a morfoestrutura e o clima.

A vegetação correspondente do município é classificada como floresta estacional semidecidual (IBGE, 1993), onde se tem a formação de ambientes menos úmidos, por se encontrar em uma zona de transição entre o ambiente costeiro e o semiárido. Uma característica marcante é que a maioria das árvores que compõe essa fitofisionomia perde boa parte das suas folhas no período seco.

A colonização da região está relacionada ao processo de busca pelo ouro que marcou o Brasil no século XVIII. Luiz Pedroso de Barros abriu caminho de São Paulo ao Rio Paraná, pelos campos de Araraquara, rumo às minas de Cuiabá (Mano, 2006). A trilha aberta na mata, chamada de Picadão, possuía muitos animais ferozes que atacavam os viajantes, o que forçou 
a construção de ranchos para o repouso dos tropeiros ao longo dos caminhos. São Pedro é o desenvolvimento de um desses ranchos. Assim, logo São Pedro se tornou um povoado com exploradores à procura de terras novas para a cultura do café, da cana-de-açúcar e da pecuária extensiva.

O município também ficou marcado quando no início da década de 1920, durante perfurações, a procura de petróleo em São Pedro foi descoberta águas medicinais bicabornatadas, sulfatadas e sulfurosas (Bizinha, 2013).

Atualmente a economia de São Pedro é representada primeiramente pelo setor de serviços, a seguir pelo setor industrial e por último pelo setor agropecuário (IBGE, 2010).

\section{2 - Mosaico de fotografias aéreas}

Foram utilizadas fotografias aéreas de alta resolução espacial e ortofotos do ano de 2010/2011, cedidas pela Empresa Paulista de Planejamento Metropolitano (EMPLASA), através do Contrato de Licença e Uso - CLU no 073/15, do Projeto de Atualização Cartográfica do Estado de São Paulo. Esse projeto teve por finalidade gerar uma base única de informações cartográficas oficial, completa e atualizada, para uso comum, de forma a apoiar os processos de gestão do território do Estado de São Paulo.

A resolução espacial das fotografias é de 0,45 metros, capturadas nos períodos secos, no inverno e as câmeras utilizadas foram as Ultracam, modelo X e XP. As fotografias têm superposição lateral de $60 \%$ e $30 \%$ entre as faixas de voo, assegurando assim a visão tridimensional e o recobrimento total da área. Na presente pesquisa foi utilizado um conjunto de 4 fotografias aéreas.

A utilização de fotografias aéreas possibilita obter informações qualitativas e quantitativas a respeito de diversas coberturas e uso da terra (plantações, áreas de preservação, áreas de queimadas, urbanização, entre outras). As imagens captadas por câmaras fotográficas servem de base para a localização de objetos no espaço e permite uma visão tridimensional a partir da estereoscopia. Os registros das imagens do terreno são feitos em relação aos aspectos fisiográficos (topografia, vegetação e drenagem), que se apresentam distintos na forma, tamanho, cor, sombra, textura e padrão.

\subsection{1 - Mapeamento dos Fragmentos Florestais}

O mapeamento dos fragmentos florestais foi elaborado por interpretação visual na escala 1:1500 no programa ArcGis 10.1. Na etapa de análise espacial foram levados em conta os fragmentos de formações florestais e áreas reflorestadas. A distinção dos fragmentos foi feita considerando as características texturais, padrão de sombreamento, pois as áreas de reflorestamento possuem uma textura mais homogênea de sombreamento definida em padrões linear, enquanto as áreas naturais se distinguem por possuir maiores variações de textura. 
Para averiguar as consequências da fragmentação foram utilizados alguns parâmetros considerados importantes: a quantidade, composição e distribuição dos fragmentos.

\subsection{2 - Delimitação das Áreas de Proteção.}

As áreas de Preservação Permanente (APPs) foram definidas pelo Código Florestal de 1965, e atualmente são geridas pela Lei 12.651 (novo Código Florestal Brasileiro), de 2012. Essa nova legislação trouxe algumas modificações, como as definições para as APPs no que diz respeito às matas ciliares, topos de morros e áreas acima de $1800 \mathrm{~m}$ de altitude. $O$ papel das APPs é fundamental e estas se constituem como uma proteção do ambiente natural, sendo proibido qualquer tipo de alteração na vegetação natural.

$\mathrm{O}$ art. $3^{\circ}$, inciso II da Lei 12.651 , define que a APP consiste em uma área protegida, coberta ou não por vegetação nativa, com a função ambiental de preservar os recursos hídricos, a paisagem, a estabilidade geológica e a biodiversidade, facilitar o fluxo gênico de fauna e flora, proteger o solo e assegurar o bem-estar das populações humanas (Brasil, 2012).

Essa lei delimita as faixas de APPs ao longo do curso d'água, natural perene ou intermitente, e neste trabalho são consideradas apenas as APPs de 30 metros, relacionadas à cursos d'água com menos de menos de 10 metros de largura, além da APP de 50 metros para as áreas no entorno das nascentes. O mapa de APPs foi gerado no programa Arcgis 10.1, utilizando as drenagens como parâmetro, tanto para gerar buffer de $30 \mathrm{~m}$ para o curso d'água quanto para gerar o buffer das nascentes.

A manutenção da qualidade dos recursos hídricos depende diretamente das características da área ao seu redor, que os protege e possibilita sua manutenção na forma natural (Guimarães at al., 2015), proporcionando a infiltração, diminuindo os riscos de erosão, de assoreamento, além de servirem como corredores ecológicos. As áreas de preservação permanente tem um papel fundamental na busca pelo desenvolvimento sustentável por isso tem previsão legal.

O cruzamento dos dados do mapa de fragmentos florestais elaborado anteriormente com o mapa das APPs permitiu avaliar o seu grau de preservação.

\subsection{3 - Métricas de Fragmentação da Paisagem}

Para cálculo das métricas de paisagem foi utilizado o programa ArcGis 10.1, por meio da extensão Patch Analyst 5.0. As métricas foram calculadas no Spatial Statistics que possibilitou compreender o grau da fragmentação florestal e de reflorestamento. Diferentes métricas foram utilizadas referentes aos seguintes aspectos: área, densidade, tamanho, variabilidade, borda e forma.

As métricas referentes à área foram: área de classe (CA) e área total (TLA), que são as mais básicas para a análise da paisagem, sendo muito utilizadas em estudos ecológicos por quantificarem o tamanho dos fragmentos existentes analisando sua composição. $O$ tamanho do 
fragmento é um fator importante para a dinâmica populacional e os efeitos de borda podem reduzir ainda mais a área efetiva do fragmento para determinadas espécies (Kapos, 1989).

As métricas referentes à densidade, tamanho e variabilidade foram: número de fragmentos (Nump), tamanho médio dos fragmentos (MSP), desvio padrão do tamanho dos fragmentos (PSSD), coeficiente de variação do tamanho do fragmento, que é a relação entre o desvio padrão e a média do tamanho dos fragmentos (PSCoV). Essas métricas trazem informações quanto à configuração da paisagem, caracterizando assim elementos da fragmentação florestal.

Quanto às características de borda (configuração) foram adotados os índices: borda total (TE), que indica o tamanho da borda da classe, em metros; e densidade de borda (ED), que mostra a relação entre a extensão da borda por hectare. Vários fenômenos ecológicos se caracterizam pela quantidade total de bordas, e a informação sobre as bordas (que pode caracterizar o efeito de borda) é um importante aspecto estudado pelos investigadores ecológicos. Como já afirmado, o efeito de borda em fragmentos florestais resulta em diferentes intensidades de vento e intensidade e qualidade de iluminação solar, produzindo microclimas e taxas de distúrbio (McGarigal; Marks, 1995).

Em relação às métricas de forma (configuração) foram utilizados: o índice de forma média (MSI), índice de forma média ponderada pela área (AWMSI), dimensão fractal da mancha média (MPFD), somatório da razão perímetro/área divido pelo número de fragmentos (MPAR), complexidade dos fragmentos (AWMPF), média da quantidade borda por fragmento (MPE), mediana do tamanho do fragmento (medPS). O fator forma é um parâmetro favorável para a análise da vulnerabilidade dos fragmentos a perturbações, especialmente através do efeito de borda (Viana e Pinheiro, 1998) e que influencia nas ações inter-fragmentos.

\subsection{4 - Análise do Padrão Espacial Morfológico}

A metodologia de análise morfológica também foi utilizada na análise dos fragmentos da paisagem. O processamento dos dados morfológicos foi realizado no programa GUIDOS. A Análise de Padrões Espaciais Morfológicos (Morphological Spatial Pattern Analysis - MSPA) difere das métricas tradicionais, pois classifica todos os remanescentes de vegetação natural, sendo formada por operadores matemáticos a partir de imagens binárias determinadas, florestais e não florestais, que descrevem a geometria e a conectividade dos componentes da imagem. Assim, a conversão dos mapas que estavam em formato vetorial para o formato raster é necessária, pois o dado de entrada desse programa é binário. Admite-se apenas três tipos de classes, atribuindo o valor 2 para a vegetação natural (florestais e reflorestados), o valor 1 para os demais usos de cobertura e o valor 0 para o quadrado fictício moldando o limite da área. É uma classificação automática que subdivide os remanescentes de vegetação natural em sete classes: núcleo, ilha, laço, ponte, borda, perfuração e ramificação.

Os núcleos (core - coloração verde) são o interior da área de interesse excluindo a área complementar. As ilhas (islet- coloração marrom) são as áreas pertencentes à área de interesse disjunta e que são muito pequenas para possuírem um núcleo. Os laços (loop- 
coloração amarela) e as pontes (bridge - coloração vermelha) são os chamados conectores, pois pertencem à área de interesse que se conectam com os núcleos. Os laços conectam dentro da mesma área de núcleo, enquanto as pontes conectam duas áreas de núcleo diferentes, formando os corredores. As classes perfuração (perforation - coloração azul) e borda (edge - coloração preta) determinam os limites da área de núcleo e por isso são de fronteira. As perfurações são regiões que estão começando a ter um uso dentro de uma área núcleo, fator que demonstra o quanto intenso está sendo o uso na área e as bordas são os limites externos da área núcleo. E os pixels que não pertencem a nenhuma categoria são chamados de ramo (branch - coloração laranja).

Para análise das APPs foram simulados 4 cenários estruturais considerado as métricas da paisagem do MSPA:

(a) Cenário 1: apenas remanescentes da vegetação natural;

(b) Cenário 2: remanescentes da vegetação natural + área reflorestada;

(c) Cenário 3: remanescentes da vegetação natural + app recuperada (simulação) e;

(d) Cenário 4: remanescentes da vegetação natural + área reflorestada + app recuperada (simulação).

Diferentes tamanhos de buffer foram utilizados, uma vez que as alterações bióticas e abióticas de um fragmento ocorrem principalmente nas bordas, influenciando a estrutura da vegetação e as comunidades de animais (Murcia, 1995; Primack \& Rodrigues, 2001; Olifiers \& Cerqueira, 2006). Para o cálculo dos atributos da MSPA foram realizadas 5 larguras de buffer $1 \mathrm{~m}$ (real), 10m, 20m, 30m e 40m - para cada cenário. 


\section{RESULTADOS}

\section{1 - Mapeamento}

O mapa de fragmentos florestais evidenciou uma extensa área desmatada, com diferentes tipos de uso. A maior parte dos remanescentes de Mata Atlântica na área de estudo encontra-se espalhadas e desconectadas (Figura 2). Esta configuração está de acordo com a descrição de vários trabalhos, que relatam a fragmentação na Mata Atlântica. Ao redor das drenagens foram identificados os fragmentos de formação florestal.

No mapa de conflito das APPs observa-se que uma boa área de APP encontra-se desmatada.

Há presença significativa de vegetação natural em alguns trechos das APP, mas também há trechos em que a APP deveria existir, porém seu valor é mínimo ou inexistente.

$\mathrm{Na}$ região analisada, as áreas de reflorestamentos são mais significativas do que os fragmentos de origem florestal, que são poucos e estão mais localizados nas áreas ao longo dos corpos d'água, local onde por lei deveria existir a APP como proteção e manutenção deste curso d'água.

\section{2 - Índices de Fragmentação}

A Tabela 1 apresenta os valores associados às métricas da paisagem, que expressam a composição e configuração dos fragmentos florestais e reflorestados. O cenário atual possui um total de 263 fragmentos sendo 206 fragmentos florestais e 57 áreas reflorestadas. Os fragmentos florestais possuem uma área total (TLA) de 472,92ha; com a seguinte configuração: 2,30ha para o tamanho médio dos fragmentos (MSP); 3,4ha para desvio padrão do tamanho do fragmento (PSSD) e 148,04\% para o coeficiente de variação do tamanho do fragmento (PSCoV). As métricas de borda foram de $197605,32 \mathrm{~m}$ de borda total (TE) e sua densidade (ED) foi de $417,84 \mathrm{~m} / \mathrm{ha}$. Quanto às métricas de forma, os índices obtidos foram: 1,82 para forma média (MSI); 2,20 para o índice de forma média ponderada pela área (AWMSI); 1,09 para a dimensão factal da mancha média (MPFD); 29318,75 para o somatório da razão perímetro/área dividido pelo número de fragmentos (MPAR); 1,13 para a complexidade dos fragmentos (AWMPF); 959,25m/fragmento para a média da quantidade de borda por fragmento e 1,09 para a mediana do tamanho do fragmento (MedPS).

Já as áreas reflorestadas apresentaram o seguinte resultado: área total de 564 ha; com a seguinte configuração: 9,90ha para o tamanho médio dos fragmentos (MSP); 17,06ha para desvio padrão do tamanho do fragmento (PSSD) e 172,30\% para o coeficiente de variação do tamanho do fragmento (PSCoV). As métricas de borda foram de 79159,51m de borda total (TE) e sua densidade (ED) foi de $140,23 \mathrm{~m} / \mathrm{ha}$. Quanto às métricas de forma, os índices obtidos foram: 1,39 para forma média (MSI); 1,48 para o índice de forma média ponderada pela área (AWMSI); 1,06 para a dimensão factal da mancha média (MPFD); 380,31 para o somatório da razão perímetro/área dividido pelo número de fragmentos (MPAR); 1,06 para a complexidade 
dos fragmentos (AWMPF); 1388,76m/fragmento para a média da quantidade de borda por fragmento e 3,16 para a mediana do tamanho do fragmento (MedPS). 


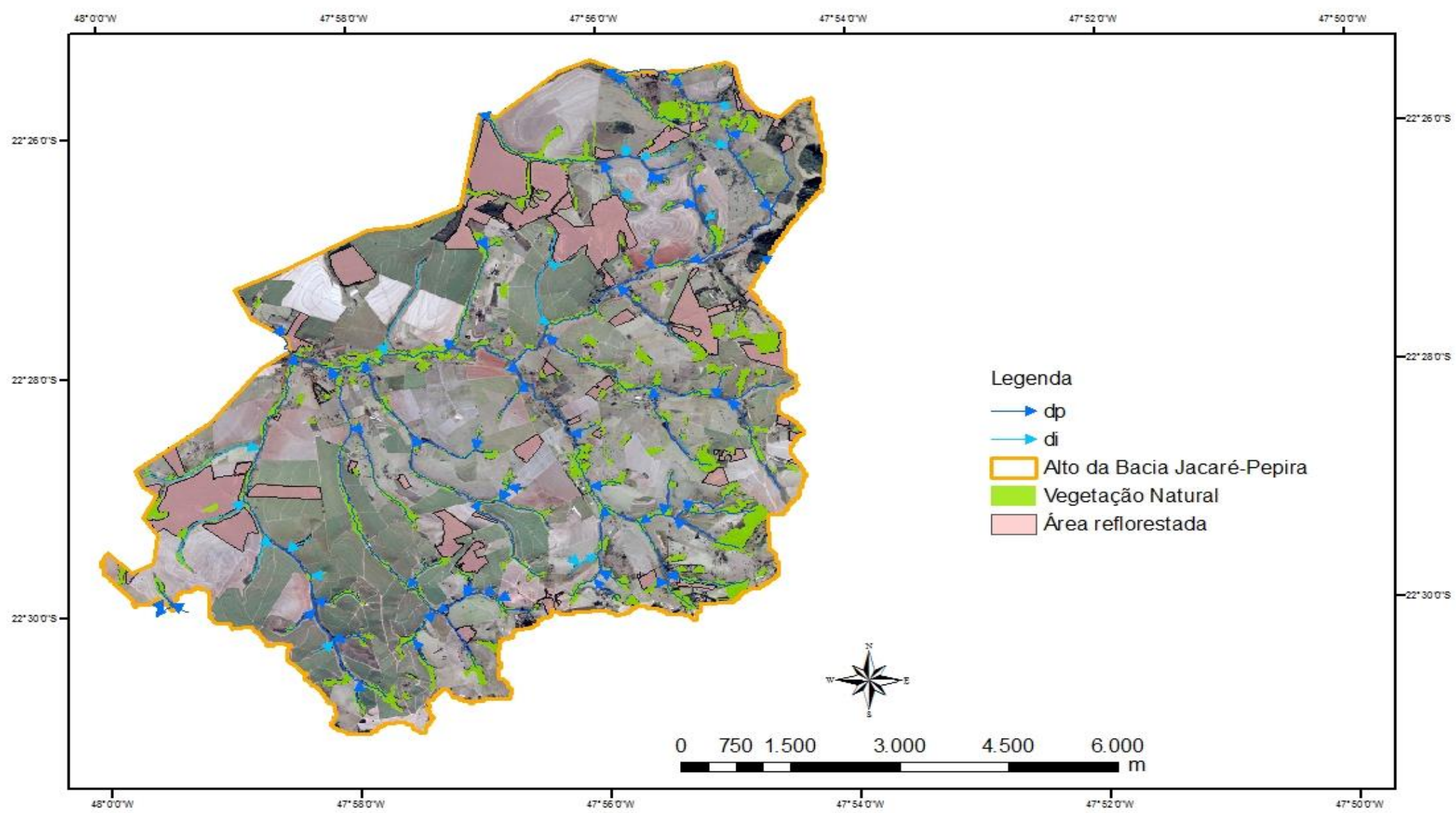

Figura 2: Mapeamento da vegetação natural e reflorestada na Alta bacia do Jacaré-Pepira. 


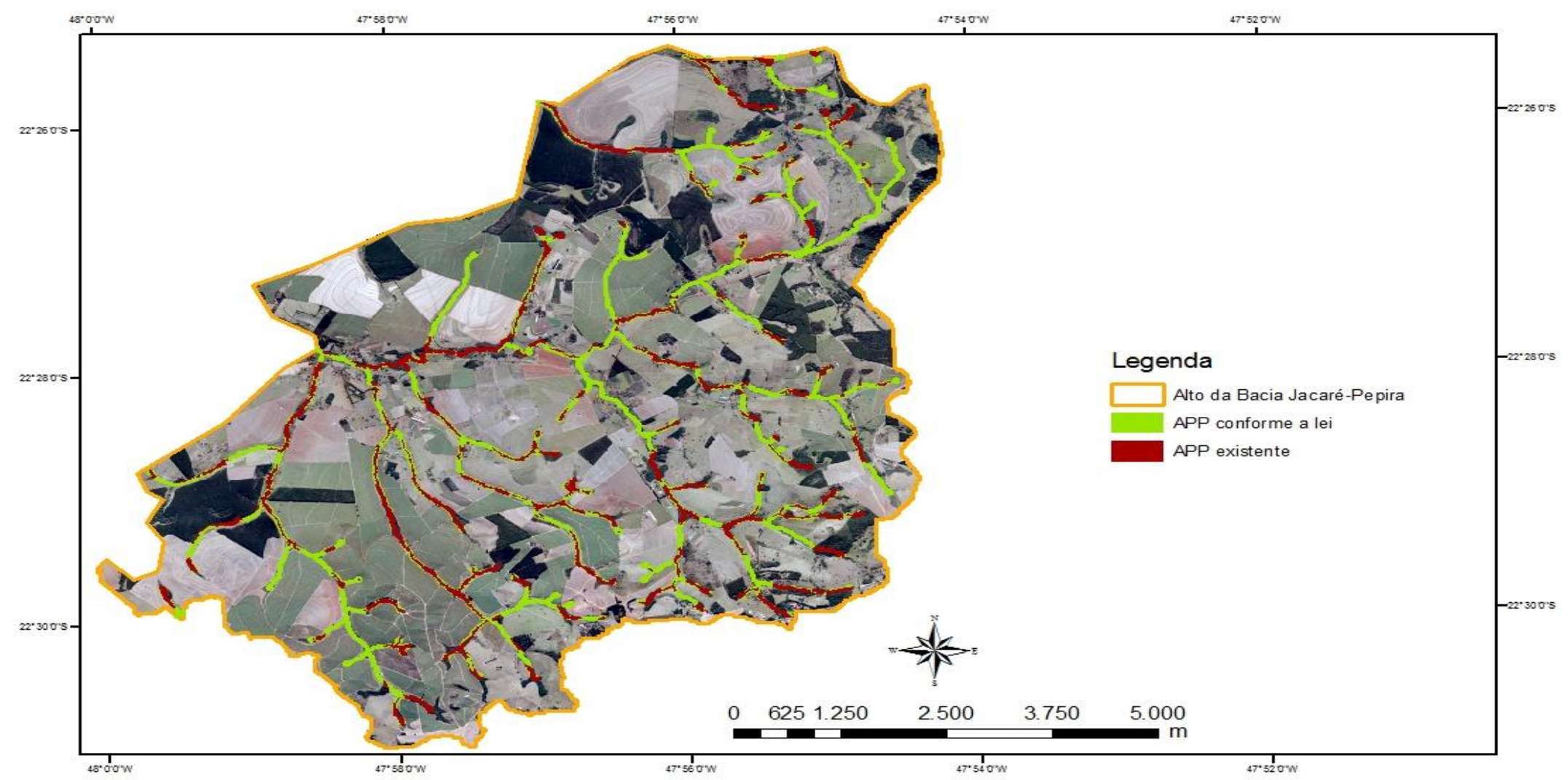

Figura 3: Mapa de conflito das APPs. 
Tabela 1: Métricas do Spatial Statistic referentes à composição e configuração dos fragmentos florestais e reflorestados.

\begin{tabular}{|c|c|c|c|}
\hline MÉTRICAS & SIGLA & $\begin{array}{c}\text { DISPOSIÇÃO } \\
\text { DOS } \\
\text { FRAGMENTOS } \\
\text { FLORESTAIS }\end{array}$ & $\begin{array}{c}\text { DISPOSIÇÃO DAS } \\
\text { ÁREAS } \\
\text { REFLORESTADAS }\end{array}$ \\
\hline \multicolumn{4}{|l|}{ MÉTRICAS DE ÁREA (COMPOSIÇÃO) } \\
\hline Área da classe (ha) & CA & 472,92 & 564,50 \\
\hline Área total (ha) & TLA & 472,92 & 564,50 \\
\hline \multicolumn{4}{|l|}{$\begin{array}{l}\text { MÉTRICAS DE DENSIDADE, TAMANHO E } \\
\text { VARIABILIDADE (CONFIGURAÇÃO) }\end{array}$} \\
\hline Número de fragmentos & NumP & 206 & 57 \\
\hline Tamanho médio dos fragmentos (ha) & MSP & 2,30 & 9,90 \\
\hline $\begin{array}{l}\text { Desvio padrão do tamanho do fragmento } \\
\text { (ha) }\end{array}$ & PSSD & 3,40 & 17,06 \\
\hline $\begin{array}{l}\text { Coeficiente de variação do tamanho do } \\
\text { fragmento }(\%)\end{array}$ & PSCoV & 148,04 & 172,30 \\
\hline \multicolumn{4}{|l|}{$\begin{array}{l}\text { MÉTRICAS DE BORDA } \\
\text { (CONFIGURAÇÃO) }\end{array}$} \\
\hline Borda total (m) & TE & 197605,32 & 79159,51 \\
\hline Densidade de borda $(\mathrm{m} / \mathrm{ha})$ & ED & 417,84 & 140,23 \\
\hline \multicolumn{4}{|l|}{$\begin{array}{l}\text { MÉTRICAS DE FORMA } \\
\text { (CONFIGURAÇÃO) }\end{array}$} \\
\hline Índice de forma média & MSI & 1,82 & 1,39 \\
\hline Índice de forma média ponderado pela área & AWMSI & 2,20 & 1,48 \\
\hline Dimensão factal da mancha média & MPFD & 1,09 & 1,06 \\
\hline $\begin{array}{l}\text { Somatório da razão perímetro/área dividido pelo } \\
\text { número de fragmentos }\end{array}$ & MPAR & 29318,75 & 380,31 \\
\hline Complexidade dos fragmentos & AWMPF & 1,13 & 1,06 \\
\hline $\begin{array}{l}\text { Média da quantidade borda por fragmento } \\
\text { (m/fragmento) }\end{array}$ & MPE & 959,25 & 1388,76 \\
\hline Mediana do tamanho do fragmento (ha) & MedPS & 1,09 & 3,16 \\
\hline
\end{tabular}


A Tabela 2 apresenta os valores do cenário atual (remanescentes da vegetação natural + área reflorestada) e também os valores simulando a APP como recuperada (remanescentes da vegetação natural + área reflorestada + app recuperada- simulação). Para o cenário atual, o valor corresponde a uma área total de 1037,42 hectares, com um total de 263 fragmentos. 0 tamanho médio deles foi de 3,94ha. O desvio padrão do tamanho do fragmento é de 9,05ha e o coeficiente de variação do tamanho do fragmento é de $229,54 \%$. Já os índices correspondentes à borda foram de $276764,83 \mathrm{~m}$ de borda total e sua densidade foi de 26,78 $\mathrm{m} / \mathrm{ha}$. Quanto à configuração os índices obtidos foram: 1,73 para forma média (MSI); 1,81 para o índice de forma média ponderada pela área (AWMSI); 1,09 para a dimensão factal da mancha média (MPFD); 23046,92 para o somatório da razão perímetro/área dividido pelo número de fragmentos (MPAR); 1,09 para a complexidade dos fragmentos (AWMPF); $1052,34 \mathrm{~m} /$ fragmento para a média da quantidade de borda por fragmento e 1,40 para a mediana do tamanho do fragmento (MedPS).

Para o cenário simulado, considerando a APP recuperada, o valor corresponde a uma área total de 1645,90 hectares, com 352 fragmentos. O tamanho médio deles foi de 4,68ha. 0 desvio padrão do tamanho do fragmento é de 26,81ha e o coeficiente de variação do tamanho do fragmento é de 573,38\%. Já os índices correspondentes à borda foram de 480896,08m de borda total e sua densidade foi de $292,18 \mathrm{~m} / \mathrm{ha}$. Quanto à configuração os índices obtidos foram: 1,59 para forma média; 6,59 para o índice de forma média ponderada pela área; 1,07 para a dimensão factal da mancha média; 17319,72 para o somatório da razão perímetro/área dividido pelo número de fragmentos; 1,18 para a complexidade dos fragmentos; $1366,18 \mathrm{~m} /$ fragmento para a média da quantidade de borda por fragmento e 0,81 para a mediana do tamanho do fragmento. 
Tabela 2: Métricas do Spatial Statistics referentes ao cenário atual e ao cenário somado as APPs.

\begin{tabular}{|c|c|c|c|}
\hline MÉTRICAS & SIGLA & $\begin{array}{l}\text { DISPOSIÇÃO } \\
\text { DO CENÁRIO } 2 \\
\text { (REAL) }\end{array}$ & $\begin{array}{l}\text { DISPOSIÇÃO DO } \\
\text { CENÁRIO } 4 \\
\text { (COM AS APPS) }\end{array}$ \\
\hline \multicolumn{4}{|l|}{ MÉTRICAS DE ÁREA (COMPOSIÇÃO) } \\
\hline Área da classe (ha) & CA & 1037,42 & 1645,90 \\
\hline Área total (ha) & TLA & 1037,42 & 1645,90 \\
\hline \multicolumn{4}{|l|}{$\begin{array}{l}\text { MÉTRICAS DE DENSIDADE, TAMANHO E } \\
\text { VARIABILIDADE (CONFIGURAÇÃO) }\end{array}$} \\
\hline Número de fragmentos & NumP & 263 & 352 \\
\hline Tamanho médio dos fragmentos (ha) & MSP & 3,94 & 4,68 \\
\hline $\begin{array}{l}\text { Desvio padrão do tamanho do fragmento } \\
\text { (ha) }\end{array}$ & PSSD & 9,05 & 26,81 \\
\hline $\begin{array}{l}\text { Coeficiente de variação do tamanho do } \\
\text { fragmento }(\%)\end{array}$ & PSCoV & 229,54 & 573,38 \\
\hline \multicolumn{4}{|l|}{$\begin{array}{l}\text { MÉTRICAS DE BORDA } \\
\text { (CONFIGURAÇÃO) }\end{array}$} \\
\hline Borda total $(m)$ & TE & 276764,83 & 480896,08 \\
\hline Densidade de borda $(\mathrm{m} / \mathrm{ha})$ & ED & 26,78 & 292,18 \\
\hline \multicolumn{4}{|l|}{$\begin{array}{l}\text { MÉTRICAS DE FORMA } \\
\text { (CONFIGURAÇÃO) }\end{array}$} \\
\hline Índice de forma média & MSI & 1,73 & 1,59 \\
\hline Índice de forma média ponderado pela área & AWMSI & 1,81 & 6,59 \\
\hline Dimensão factal da mancha média & MPFD & 1,09 & 1,07 \\
\hline $\begin{array}{l}\text { Somatório da razão perímetro/área dividido pelo } \\
\text { número de fragmentos }\end{array}$ & MPAR & 23046,92 & 17319,72 \\
\hline Complexidade dos fragmentos & AWMPF & 1,09 & 1,18 \\
\hline $\begin{array}{l}\text { Média da quantidade borda por fragmento } \\
\text { (m/fragmento) }\end{array}$ & MPE & 1052,34 & 1366,18 \\
\hline Mediana do tamanho do fragmento (ha) & MedPS & 1,40 & 0,81 \\
\hline
\end{tabular}


Comparando as duas métricas da Tabela 2, o cenário atual apresenta uma área total de 1037,42ha enquanto na simulação realizada a área total deveria ser 1645,90 ha, caso as APPs fossem recuperadas respeitando a legislação. Todas as métricas referentes à densidade, tamanho, variabilidade e borda aumentariam, os números de fragmentos passariam de 263 para 352; o tamanho médio de cada fragmento seria de 4,68ha e não de 3,94ha; o desvio padrão do tamanho do fragmento que é de 9,05 aumentaria para 26,81; o coeficiente de variação do tamanho do fragmento passaria de 229,54 para 573,38\%; a borda total seria de 480896,08m e não mais de 276764,83; e sua densidade passaria de 26,78 para 292,18.

Já quanto às métricas de forma os valores obtidos para o índice de forma média, o índice de forma média ponderada pela área, a complexidade dos fragmentos, a média da quantidade borda por fragmento ( $\mathrm{m} /$ fragmento) aumentaram. Enquanto os valores da Dimensão factal da mancha média, do Somatório da razão perímetro/área dividido pelo número de fragmentos e da Mediana do tamanho do fragmento (ha) diminuíram.

A Tabela 1 e Tabela 2 expressam fatores relevantes a respeito da composição e da configuração dos fragmentos. As métricas demonstram que a área contém 263 fragmentados e se caso toda a APP fosse recuperada apresentaria 352 fragmentos. A densidade de borda foi uma das métricas que mais apresentou variação, sendo que seu valor foi de 26,78 , caso fosse recuperada a APP seu valor passaria para 292,17.

\section{3 - Simulação de Cenários Estruturais}

Com a abordagem da MSPA foi possível conferir se os fragmentos apresentam conectividade entre os fragmentos entre si.

A Figura 4 apresenta o cenário composto apenas pela área de vegetação natural. Pode-se observar que, mesmo simulando um aumento de área a partir da borda com um buffer de $40 \mathrm{~m}$, não haveria conectividade entre os fragmentos. Na Figura 5 o cenário simulado foi com a área de vegetação natural somado à área de reflorestamento, que é o cenário atual da área trabalhada, o que não teve uma representatividade nos conectores florestais. Na Figura 6 o cenário considerou a APP como recuperada e somou com a vegetação natural, onde é possível observar um grande número de pontes entre os fragmentos mesmo com a borda medindo apenas $10 \mathrm{~m}$. Por fim a Figura 7 , que considerou todos os cenários possíveis: a vegetação natural, a área reflorestada e as APPs recuperadas, é possível visualizar todos os fragmentos conectados, sendo os resultados muito parecidos ao do cenário 3 .

Na Figura 4, o cenário 1 apresentou pouca área núcleo, pouca ponte e muito ramo com todos os buffers, e no buffer de $40 \mathrm{~m}$ apresentou alguns laços. A partir do buffer de $10 \mathrm{~m}$ se tem o aparecimento de ilhas no cenário. Na Figura 5, a área núcleo aumenta a partir do buffer de $1 \mathrm{~m}$, mas ainda apresenta ramo. No buffer de $40 \mathrm{~m}$ apresenta alguns laços e algumas poucas pontes. E a partir do buffer de $20 \mathrm{~m}$ se tem o aparecimento de ilhas. Na Figura 6, a área núcleo também já é considerável a partir de 1m, nos buffers de 1, 10, 20 e 30m não apresenta ramos, ao contrário dos cenários anteriores, e a partir do buffer de $30 \mathrm{~m}$ apresenta muitas pontes e quase nenhuma ilha. $O$ cenário 4 é muito semelhante ao cenário 3 , só que não apresenta ilhas. 


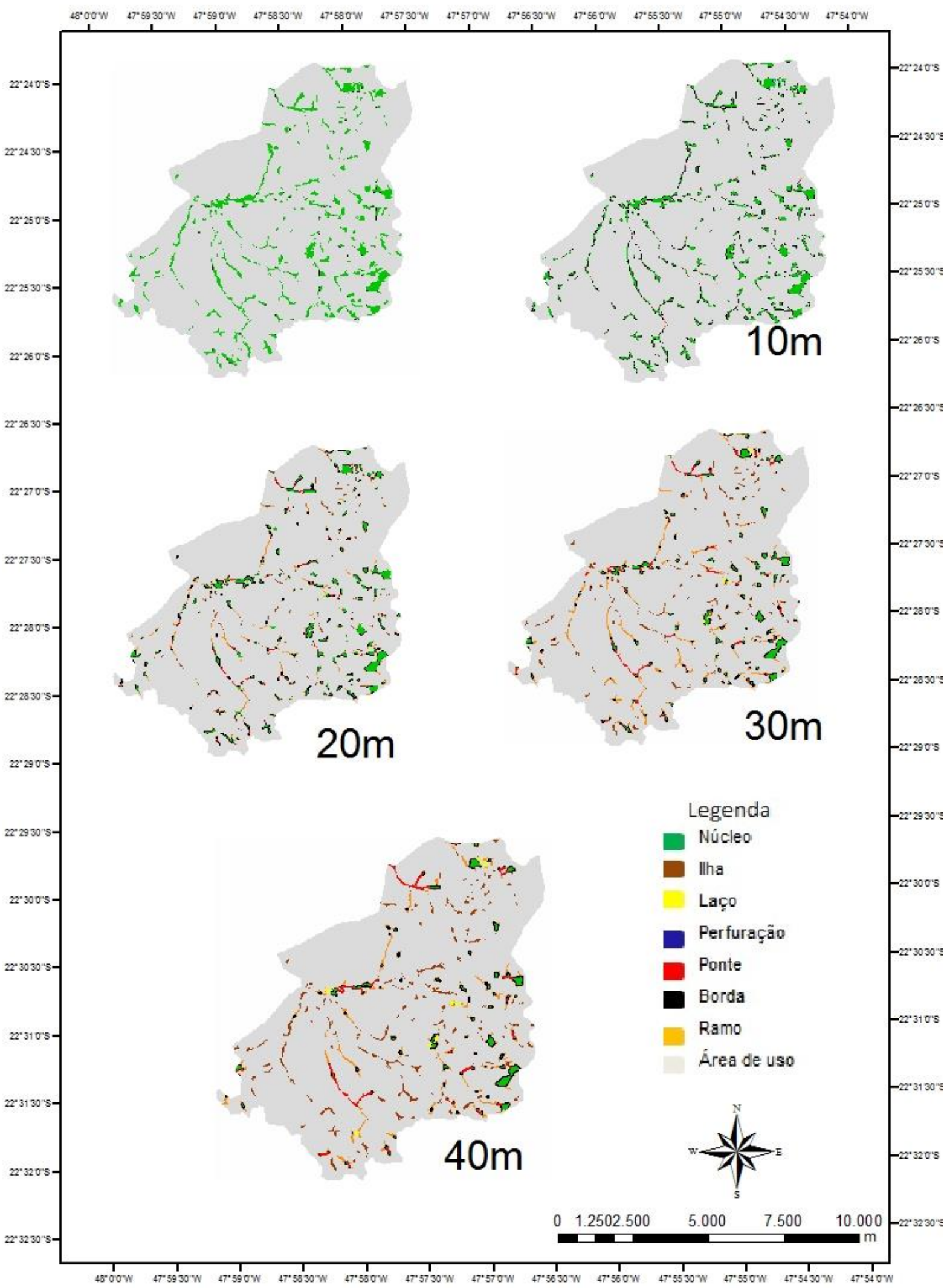

Figura 4: Efeito da variação a partir da largura do buffer da MSPA no cenário 1. 


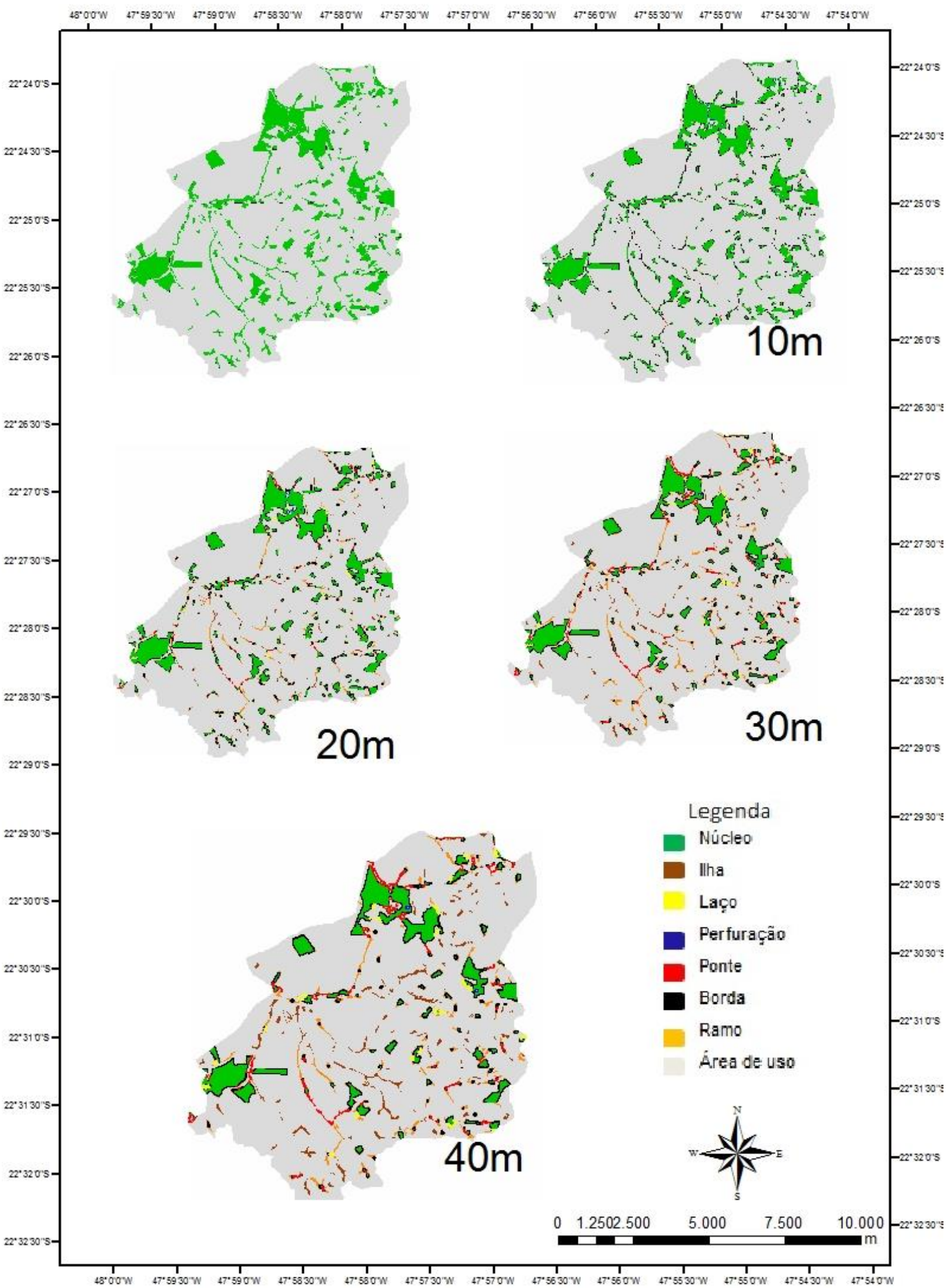

Figura 5: Efeito da variação a partir da largura de buffer da MSPA no cenário 2. 


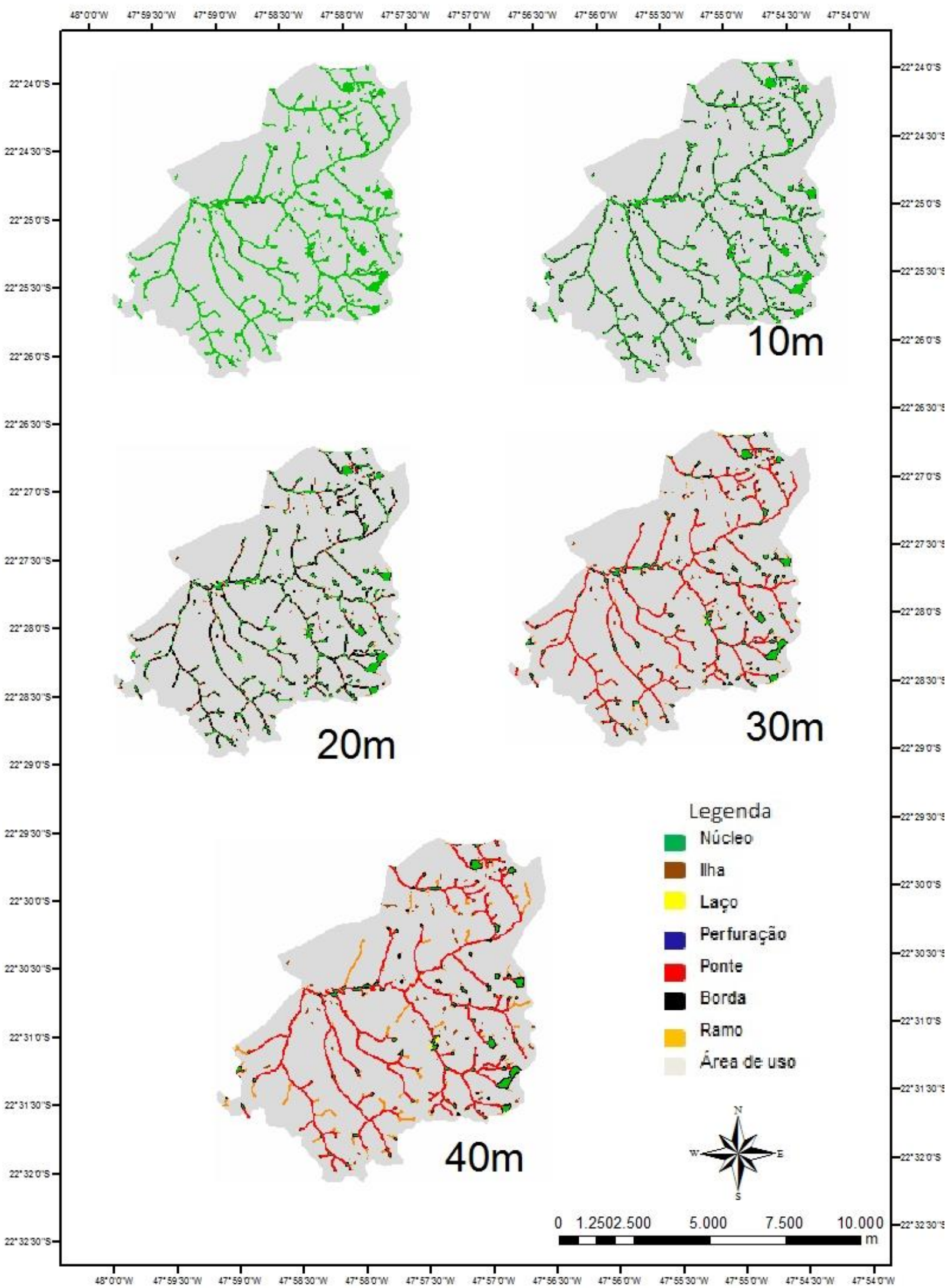

Figura 6: Efeito da variação a partir da largura do buffer da MSPA no cenário 3. 


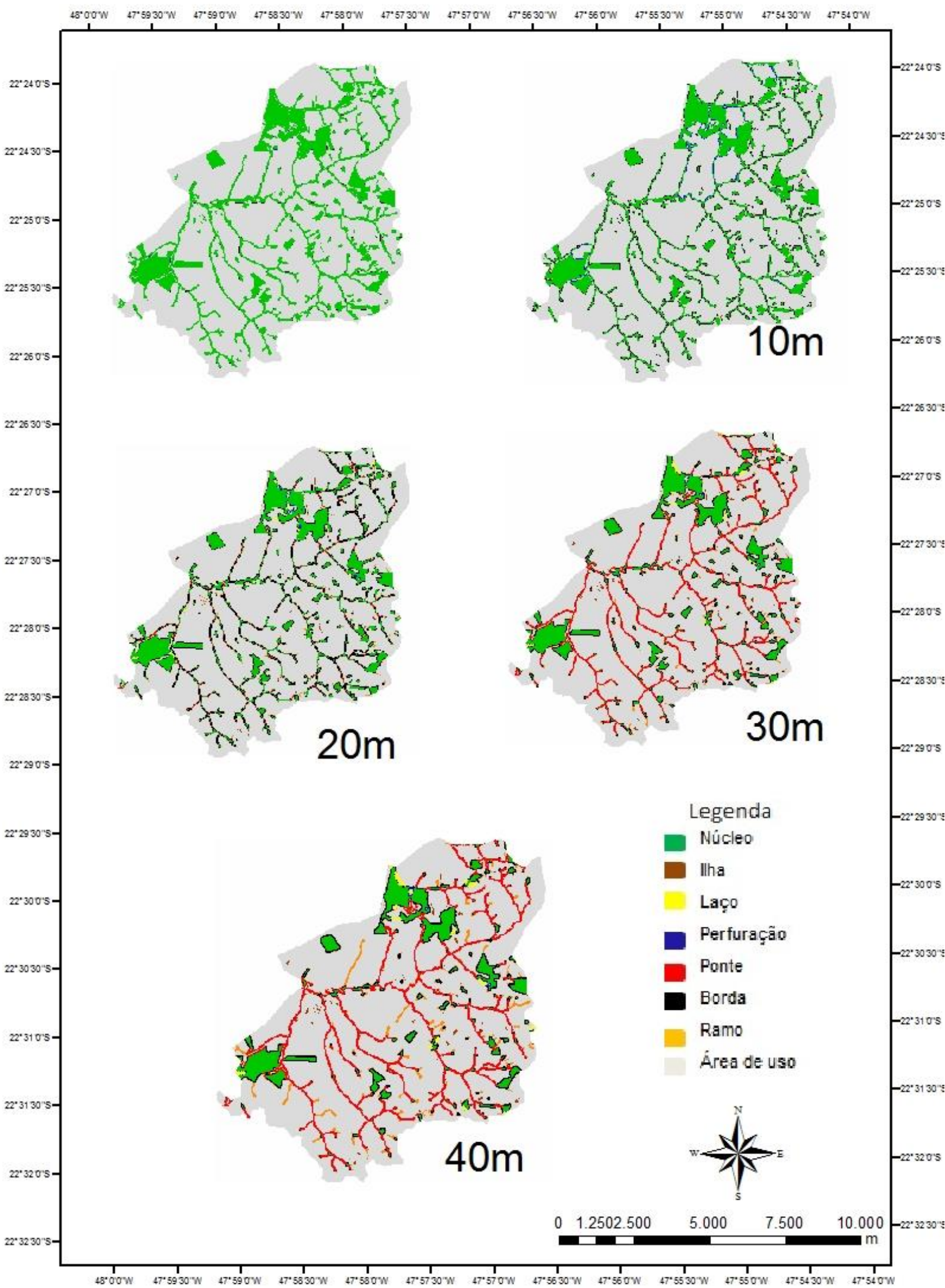

Figura 7: Efeito da variação a partir da largura do buffer da MSPA no cenário 4. 
A Tabela 3 classifica os resultados da MSPA obtidos para os quatro cenários simulados. A inclusão de APP no cenário real aumentou a porcentagem de área de pontes nas três simulações de cenários, já que o cenário 1 é com a vegetação natural apenas. No entanto, as simulações de tamanho de buffer, com a vegetação natural, não resultaram em aumento significativo de área da classe ponte. A inclusão de APP nos cenários simulados diminuiu da área o número de ilhas, em alguns cenários praticamente zerando-os.

No cenário 1, a área núcleo iniciou com $95,56 \%$ e no buffer de $40 \mathrm{~m}$ era apenas de $10,19 \%$ da área total. Apresentava 0\% de ilha, mas nos buffers de 20, 30 e 40m apresentou respectivamente 0,$45 ; 1,12$ e 2,3\% da área total. As pontes que possuíam valor 0 passaram para 0,84 no buffer de $40 \mathrm{~m}$.

No cenário 2, a área núcleo iniciou com $96,39 \%$ e no buffer de $40 \mathrm{~m}$ era apenas de $11,95 \%$ da área total. Apresentava 0\% de ilha, mas nos buffers de 20, 30 e 40m apresentou respectivamente 0,$1 ; 0,31$ e $0,36 \%$ da área total. As pontes que possuíam valor 0 passaram para 1,61 no buffer de $40 \mathrm{~m}$.

No cenário 3, a área núcleo iniciou com $96,39 \%$ e no buffer de $40 \mathrm{~m}$ era apenas de $11,95 \%$ da área total. Apresentava 0\% de ilha, mas nos buffers de 20, 30 e 40m apresentou respectivamente 0,$1 ; 0,31$ e $0,36 \%$ da área total. As pontes que possuíam valor 0 passaram para 10,14 considerando o buffer de $40 \mathrm{~m}$.

No cenário 4, a área núcleo iniciou com $97,42 \%$ e no buffer de $40 \mathrm{~m}$ era de $28,44 \%$ da área total. Apresentava $0 \%$ de ilha, mas nos buffers de 20,30 e $40 \mathrm{~m}$ apresentou respectivamente 0,$1 ; 0,23$ e $0,31 \%$ da área total. As pontes que possuíam valor 0 para $1 \mathrm{~m}$ aumentaram para 8,22. 
Tabela 3: Estatísticas do MSPA.

\begin{tabular}{|c|c|c|c|c|c|c|c|c|}
\hline \multirow{2}{*}{ Cenário } & \multirow{2}{*}{ Métricas do MSPA } & \multicolumn{7}{|c|}{ Classes de fragmentos (borda de $1,10,20,30$ e 40 metros) } \\
\hline & & Núcleo & Ilha & Perfuração & Borda & Laço & Ponte & Ramo \\
\hline \multirow{10}{*}{$\begin{array}{c}\text { Cenário } \\
1\end{array}$} & Frequência (1m) & 402 & 0 & 4 & 403 & 5 & 168 & 0 \\
\hline & Frequência (10m) & 402 & 0 & 4 & 511 & 5 & 161 & 2735 \\
\hline & Frequência $(20 \mathrm{~m})$ & 239 & 94 & 0 & 307 & 4 & 90 & 1554 \\
\hline & Frequência $(30 \mathrm{~m})$ & 163 & 138 & 0 & 203 & 6 & 51 & 838 \\
\hline & \begin{tabular}{|l|} 
Frequência $(40 \mathrm{~m})$ \\
\end{tabular} & 94 & 172 & 0 & 128 & 8 & 26 & 577 \\
\hline & \% em relação a área total $(\mathbf{1 m})$ & 95,56 & 0 & 0 & 0,34 & 0 & 0 & 0 \\
\hline & \% em relação a área total $(10 \mathrm{~m})$ & 59,14 & 0 & 0,01 & 2,92 & 0 & 0,13 & 0,08 \\
\hline & \% em relação a área total $(20 \mathrm{~m})$ & 31,57 & 0,45 & 0 & 2,94 & 0,03 & 0,6 & 1,25 \\
\hline & \% em relação a área total $(30 \mathrm{~m})$ & 16,78 & 1,12 & 0 & 2,29 & 0,07 & 0,89 & 2,03 \\
\hline & \% em relação a área total $(40 \mathrm{~m})$ & 10,19 & 2,3 & 0 & 1,78 & 0,21 & 0,84 & 1,79 \\
\hline \multirow{10}{*}{\begin{tabular}{|c} 
Cenário \\
2
\end{tabular}} & Frequência (1m) & 425 & 0 & 22 & 421 & 31 & 212 & 0 \\
\hline & Frequência (10m) & 425 & 0 & 33 & 643 & 31 & 200 & 3350 \\
\hline & Frequência (20m) & 261 & 91 & 17 & 437 & 30 & 123 & 2146 \\
\hline & Frequência (30m) & 202 & 124 & 2 & 333 & 17 & 75 & 1424 \\
\hline & Frequência (40m) & 138 & 151 & 2 & 240 & 21 & 50 & 1190 \\
\hline & \% em relação a área total (1m) & 97,3 & 0 & 0,01 & 0,44 & 0 & 0 & 0 \\
\hline & \% em relação a área total $(10 \mathrm{~m})$ & 74,67 & 0 & 0,1 & 3,86 & 0,02 & 0,17 & 0,09 \\
\hline & \% em relação a área total $(20 \mathrm{~m})$ & 55,9 & 0,38 & 0,08 & 4,59 & 0,19 & 0,75 & 1,4 \\
\hline & \% em relação a área total $(30 \mathrm{~m})$ & 43,55 & 0,95 & 0,02 & 4,59 & 0,23 & 1,42 & 2,27 \\
\hline & \% em relação a área total $(40 \mathrm{~m})$ & 35,57 & 1,89 & 0,03 & 4,47 & 0,56 & 1,61 & 2,25 \\
\hline \multirow{10}{*}{$\begin{array}{c}\text { Cenário } \\
\mathbf{3}\end{array}$} & Frequência (1m) & 111 & 0 & 0 & 5 & 117 & 8 & 40 \\
\hline & \begin{tabular}{|l|} 
Frequência $(10 m)$ \\
\end{tabular} & 111 & 0 & 0 & 6 & 170 & 8 & 39 \\
\hline & Frequência (20m) & 350 & 24 & 0 & 676 & 5 & 291 & 2741 \\
\hline & \begin{tabular}{|l|} 
Frequência $(30 \mathrm{~m})$ \\
\end{tabular} & 319 & 43 & 0 & 564 & 3 & 113 & 2382 \\
\hline & Frequência (40m) & 376 & 72 & 5 & 4194 & 25 & 171 & 2160 \\
\hline & \% em relação a área total (1m) & 96,39 & 0 & 0,01 & 0,47 & 0 & 0 & 0 \\
\hline & \% em relação a área total $(10 \mathrm{~m})$ & 64,9 & 0 & 0,06 & 4,47 & 0,01 & 0,03 & 0,09 \\
\hline & \% em relação a área total $(20 \mathrm{~m})$ & 34,34 & 0,1 & 0 & 6,72 & 0,03 & 1,1 & 0,77 \\
\hline & \% em relação a área total $(30 \mathrm{~m})$ & 13,51 & 0,31 & 0 & 3,01 & 0,02 & 6,74 & 1,4 \\
\hline & \% em relação a área total $(40 \mathrm{~m})$ & 11,95 & 0,36 & 0 & 2,59 & 0,19 & 10,14 & 1,88 \\
\hline \multirow{10}{*}{$\begin{array}{c}\text { Cenário } \\
4\end{array}$} & Frequência (1m) & 129 & 0 & 46 & 136 & 50 & 61 & 0 \\
\hline & Frequência (10m) & 129 & 0 & 94 & 253 & 50 & 63 & 3622 \\
\hline & Frequência (20m) & 339 & 29 & 24 & 793 & 39 & 305 & 3145 \\
\hline & Frequência (30m) & 350 & 39 & 4 & 722 & 14 & 142 & 2793 \\
\hline & Frequência (40m) & 216 & 43 & 4 & 459 & 17 & 63 & 2134 \\
\hline & \% em relação a área total (1m) & 97,42 & 0,07 & 0,5 & 0 & 0 & 0 & 0 \\
\hline & \% em relação a área total $(10 \mathrm{~m})$ & 74,82 & 0 & 0,69 & 4,73 & 0,04 & 0,05 & 0,1 \\
\hline & \% em relação a área total $(20 \mathrm{~m})$ & 52,5 & 0,1 & 0,12 & 8,09 & 0,2 & 1,2 & 0,86 \\
\hline & \% em relação a área total $(30 \mathrm{~m})$ & 36,09 & 0,23 & 0,05 & 5,21 & 0,22 & 6,94 & 1,58 \\
\hline & \% em relação a área total $(40 \mathrm{~m})$ & 28,44 & 0,31 & 0,06 & 4,47 & 0,4 & 8,22 & 2,48 \\
\hline
\end{tabular}


Na Figura 8, é possível verificar a variação do núcleo, ilha, perfuração, borda, laço e ponte para cada cenário e para cada tamanho de buffer. À medida que se aumenta o buffer, se diminui a área núcleo para cada cenário apresentado. Já para a ilha, de acordo com o gráfico, com $1 \mathrm{~m}$ apenas o cenário 3 apresentava, e a medida que se aumentava o buffer, o cenário 1 apresentou um crescente pico nas ilhas, bem como o cenário 2 e 3 que passou a apresentálas, somente o cenário 4 que não apresentou em nenhum buffer. Na perfuração ocorreu 0 contrário, no cenário 4 com buffer $1 \mathrm{~m}$ já apresentava, e com o aumento do buffer foram diminuindo. A borda, o laço e a ponte foram aumentando junto com o tamanho do buffer.
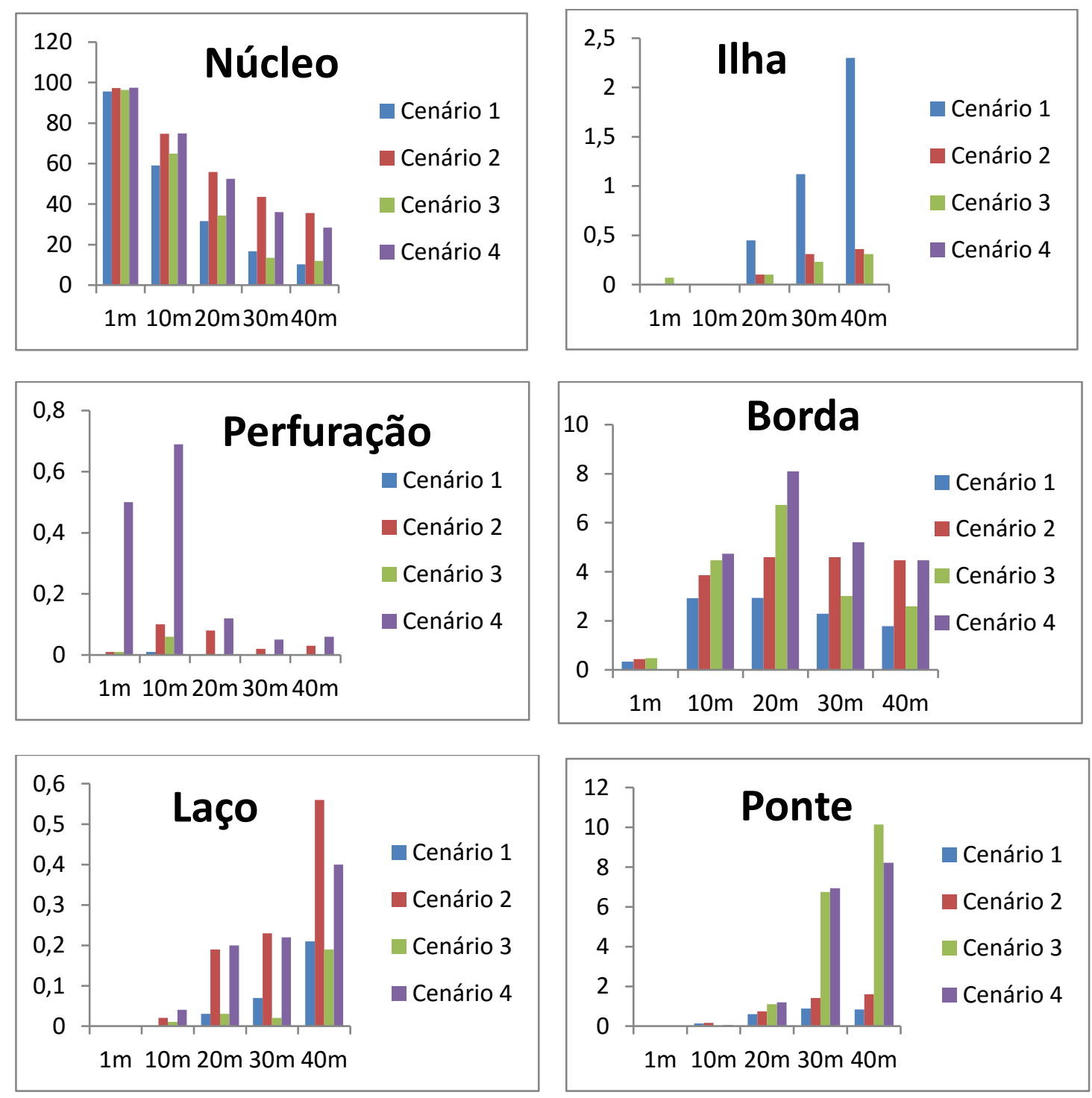

Figura 8: Resultados da MSPA da área de estudo para os 4 cenários. 
Nas Figuras 10, 11 e 12 é possível visualizar melhor os resultados da MSPA para cada cenário verificando o comportamento de cada classe. No cenário 1 , quase não há presença de classes como perfuração ou ponte. No cenário 2 é possível visualizar pouca presença de todas as classes, com exceção do núcleo. Já no cenário 3, ao contrário dos cenários anteriores, é possível ver a presença significativa de borda e ponte. O cenário 4 é muito parecido com 0 cenário 3.

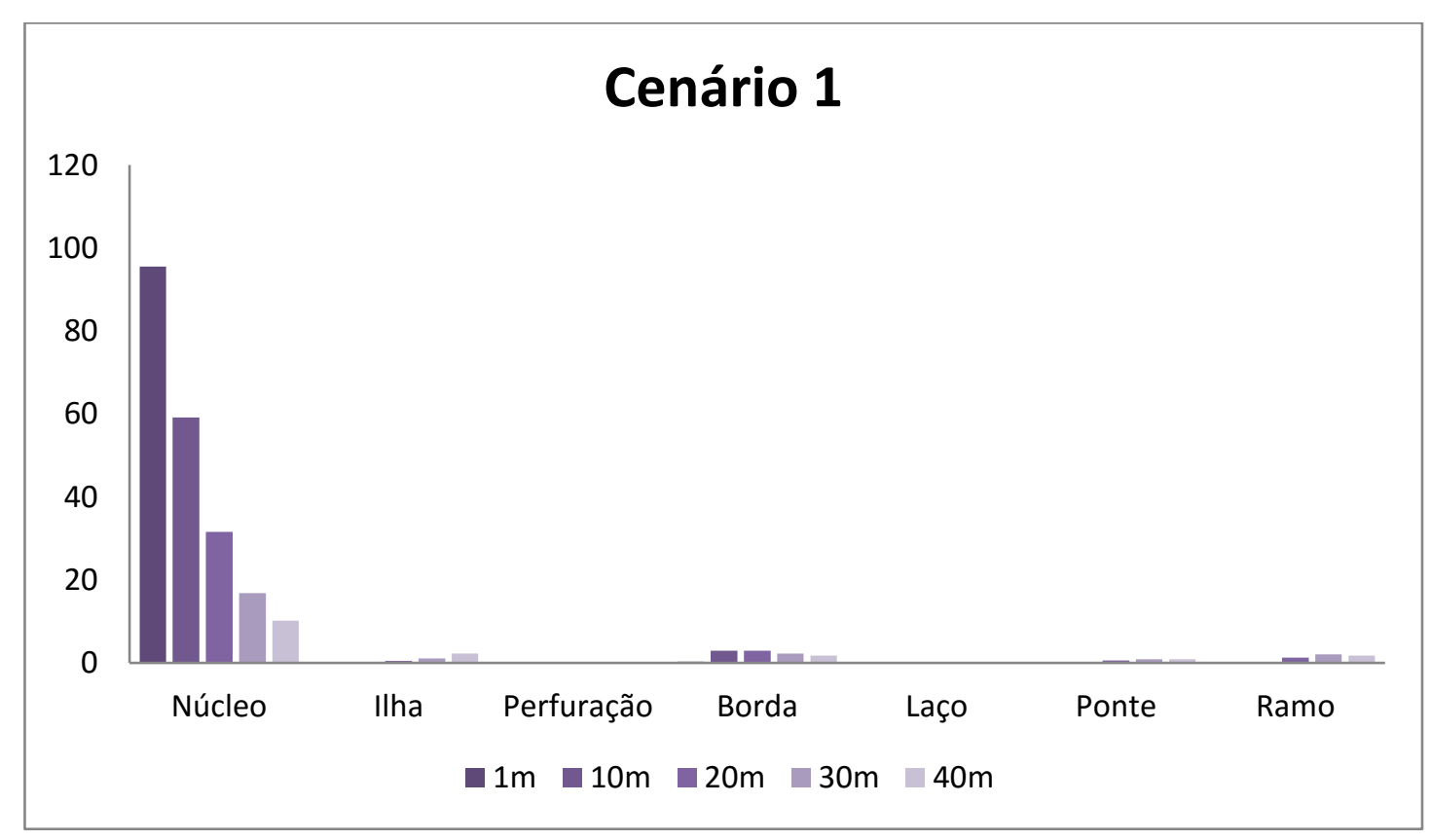

Figura 9: Resultado da MSPA do cenário 1.

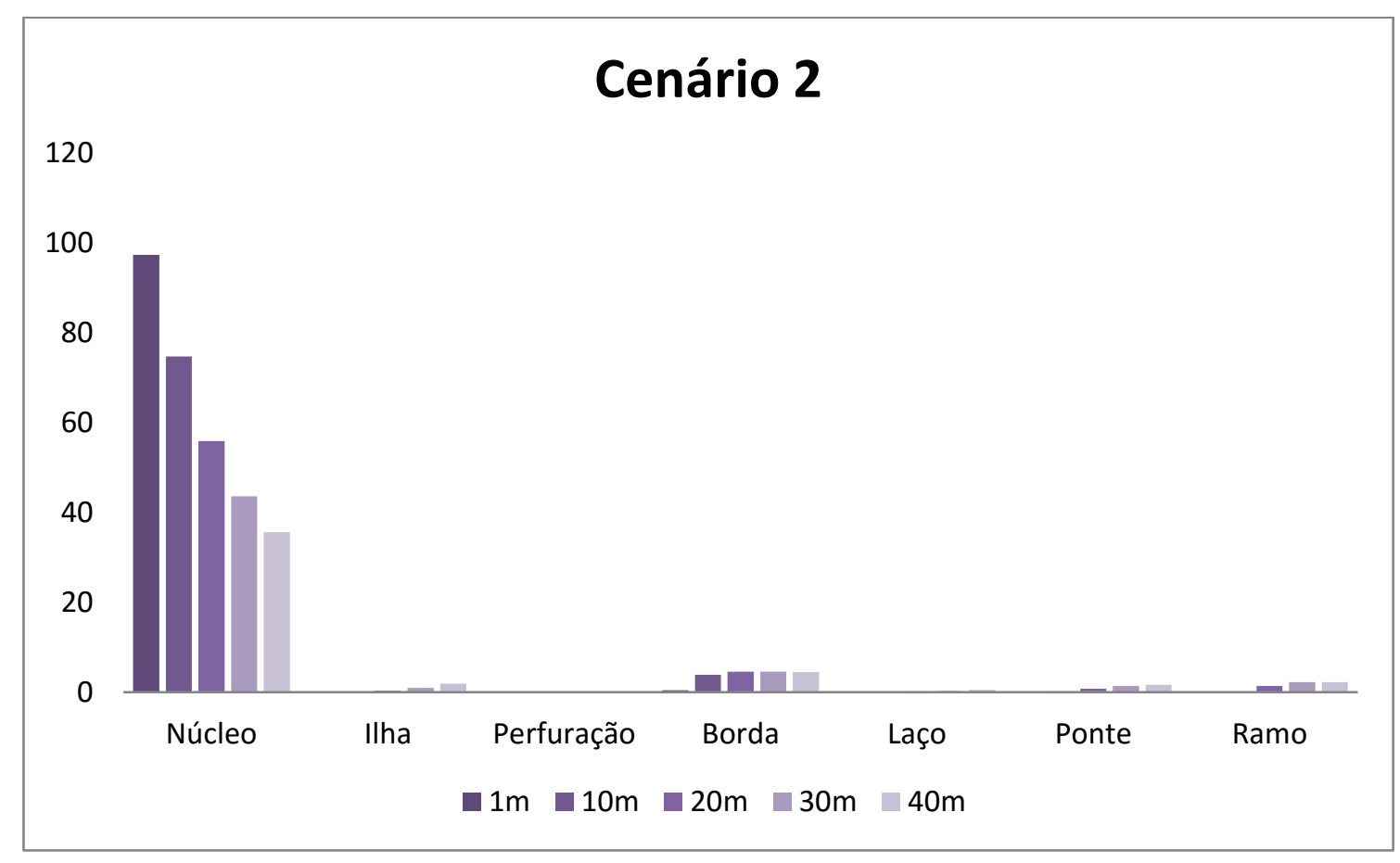

Figura 10: Resultado da MSPA do cenário 2. 


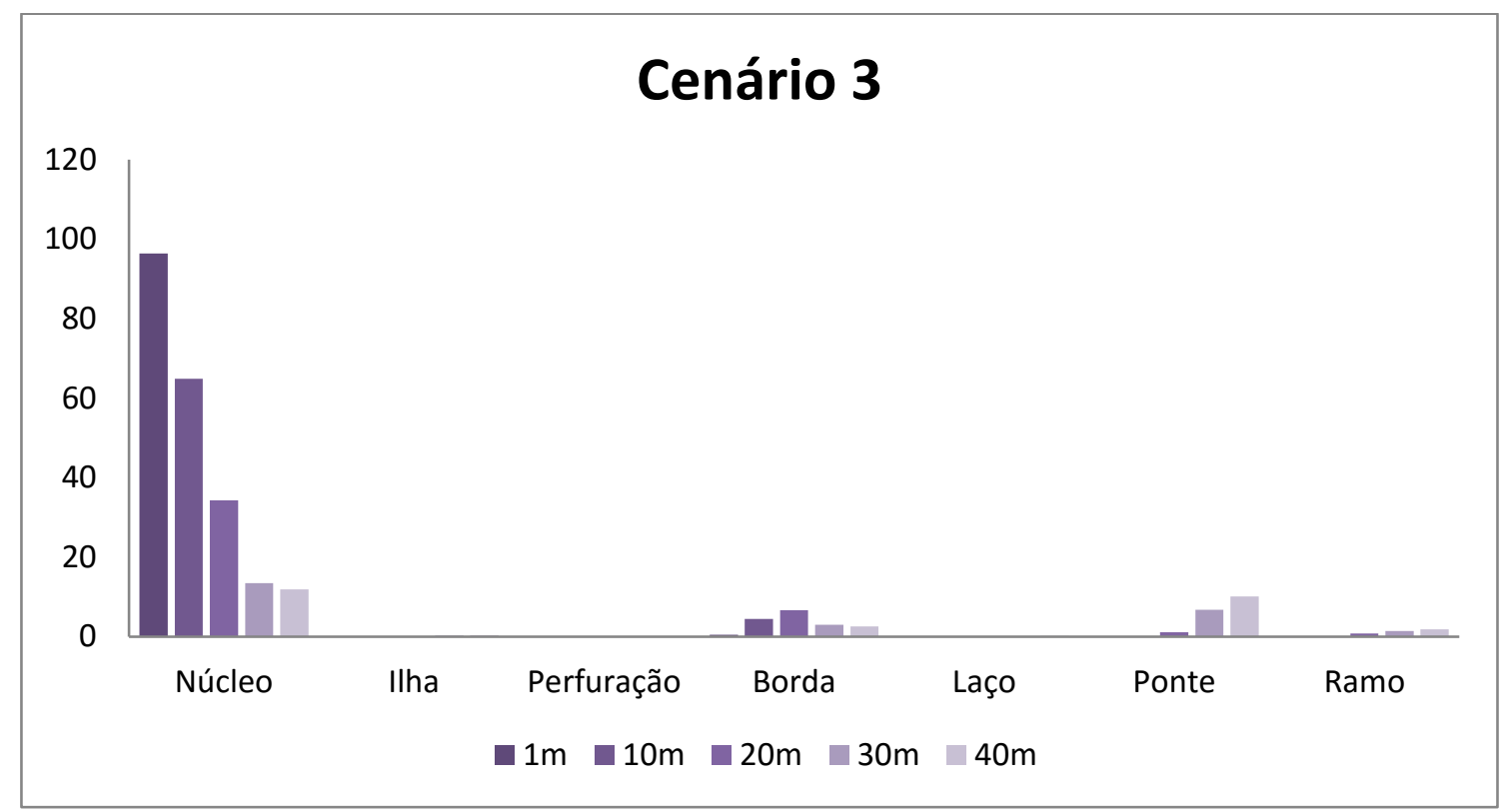

Figura 11: Resultado da MSPA do cenário 3.

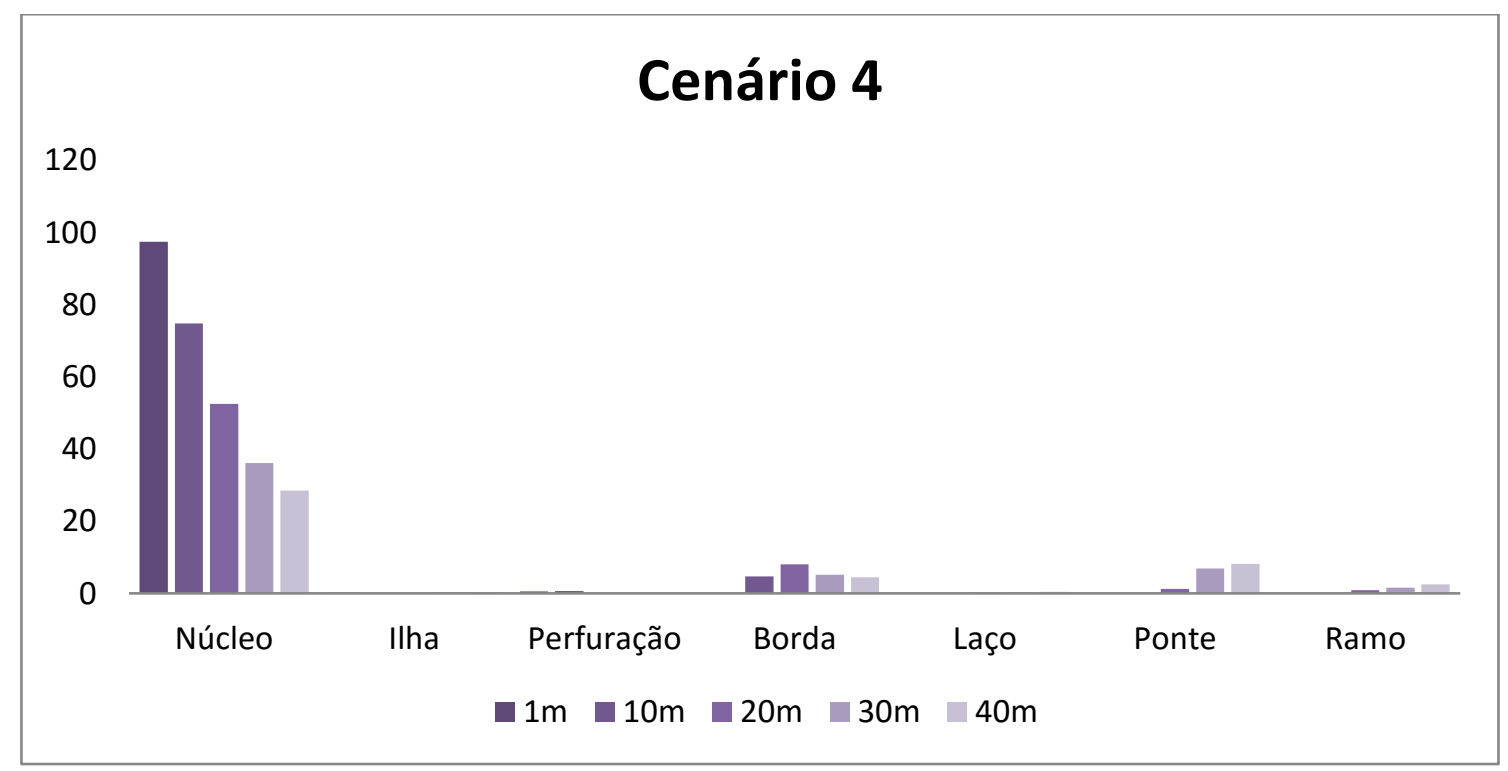

Figura 12: Resultado da MSPA do cenário 4. 


\section{DISCUSSÃO}

O mapa de conflito das APPs (Figura 2) demonstra que as APPs se encontram bastante fragmentadas, condição decorrente de intervenções antropogênicas, próprias do processo histórico de uso e ocupação do solo, evidenciando uma violação da legislação ambiental onde as APPs, principal estratégia para a conservação ambiental no Brasil, tem uso ilegal. As principais causas de degradação das APPs são o desmatamento para expansão e exploração do solo para uso humano (pecuária e agricultura). Subsídios do governo brasileiro aceleraram a expansão da agricultura e estimularam a superprodução agrícola (cana-deaçúcar, café e soja), além da extração de lenha, exploração madeireira ilegal, coleta de plantas e produtos vegetais e invasão por espécies exóticas são fatores para a degradação de matas remanescentes e perda de habitat (Galindo-Leal et al., 2003; Young, 2003; Galetti \& Fernandez, 1998).

Estudos comprovam que a largura de $30 \mathrm{~m}$ é suficiente para as matas ripárias desempenharem suas múltiplas funções como a proteção de recursos hídricos, conservação de fauna e flora além da fixação do solo (Pinay e Décamps 1988). Apesar do regime de proteção das APPs ser bastante rígido, pois a regra é a intocabilidade destas áreas, o que se vê é que seu uso ilegal é muito corriqueiro principalmente ao longo de cursos d'água, como o constatado na área de estudo, onde a finalidade das APPs tem sido ignorada acarretando assim graves prejuízos ambientais. Uma crítica fundamental contra APPs é a relativa falta de trabalho empírico demonstrando o seu efetivo aumento da conectividade (Lima e Gascon 1999).

Neste trabalho, várias simulações de cenários de métricas da MSPA foram idealizadas considerando um aumento nos buffers das áreas florestais existentes. A fixação e preservação de áreas protegida por lei somada à área de vegetação natural já existente e a área de reflorestamento garantem a conservação e melhoram a conectividade estrutural. A capacidade de dispersão das espécies depende da conectividade funcional da paisagem circundante (Tischendorf e Fahrig de 2000, Ricketts, 2001, Vandermeer e Carvajal, 2001 e Nowakowski et al., 2012) que é determinado pela ligação estrutural em conjunto com a capacidade comportamental e fisiológica para os organismos se moverem entre os fragmentos (Khazan, 2014). Corredores ecológicos constituem uma estratégia eficaz para limitar o declínio da biodiversidade em habitats florestais fragmentados (Bailey, 2007 e Gilbert-Norton et al., 2010), sendo um exemplo de manejo conservacionista que consente o fluxo gênico entre populações de espécies da fauna e da flora isoladas nos fragmentos florestais, cultivando assim a integridade ecológica das florestas $A$ fragmentação das florestas tropicais pode favorecer 0 processo de extinção, pois existem espécies que ocorrem em densidades populacionais muito baixas que participam de interações ecológicas muito reduzidas e complexas com outras espécies. Assim, a extinção de uma espécie, que mantém relações de dependência com outras, pode promover o desaparecimento das demais com as quais ela interage (MYERS, 1987). Desta forma, a fragmentação florestal pode ter consequências graves, incluindo a perda 
de habitat viável para espécies animais e vegetais (MENDOZA et al., 2005), o aumento da concorrência de espécies generalistas (LAURANCE et al., 2009), isolamento genético de subpopulações (GOOSEM et al., 2007) e todos esses fatores podem vir a resultar em extinções locais de espécies dependentes das florestas nativas (LAURANCE et al., 2009).

De acordo com a baixa densidade de APPs os resultados dos cenários simulados eram influenciados, principalmente na classe ponte. Padrão, conectividade e fragmentação podem ser considerados como pilares para uma análise quantitativa de imagens da paisagem digitais (Vogt, 2013). As APPs ajudam a manter esse nível de conectividade em paisagens florestais fragmentadas, sendo de grande importância para árvores, insetos, anfíbios, grandes e pequenos mamíferos e aves (Metzgeret al. 1997; Lima e Gascon 1999; Tubelis et al. 2004; Uezu et al. 2005; Lees e Peres 2008; Moura e Schlindwein 2009). O aumento ou a manutenção da conectividade da paisagem pode reduzir a extinção de espécies (Viana e Pineiro, 1998).

As APPs são de suma importância como corredores estruturais, considerado as métricas da paisagem do MSPA, pois nos cenários em que foram consideradas como recuperadas houve uma conectividade entre os fragmentos. De acordo com o resultado do MSPA do cenário 3 e do cenário 4 , o aumento da área preservada trouxe muitos outros benefícios com a diminuição das ilhas, o aumento da área núcleo, aumento das pontes. $\mathrm{A}$ largura do buffer também influenciou, demonstrando que quanto mais espessa for menor serão as áreas sensíveis.

Apesar das APPs terem previsão legal, ainda falta muito para que sejam acatadas. $\mathrm{O}$ Brasil é o país que abriga o maior número de espécies de plantas, animais e microrganismos do mundo. Mas para que toda essa biodiversidade seja conservada, o Código Florestal deveria servir de embasamento para políticas públicas, sendo respeitados. 


\section{CONCLUSÃO}

Atualmente a maior parte da biodiversidade da Mata Atlântica encontra-se localizada em pequenos fragmentos, onde $O$ uso adequado das terras é o primeiro passo para a preservação e conservação dos recursos naturais e para a sustentabilidade. A MSPA demonstrou a eficiência das APPs dependendo de vários fatores, entre eles a largura da buffer e o estado de conservação da vegetação preservada, podendo ser observado com a simulação de cenários que a conexão entre os fragmentos aumenta quando a APP é respeitada.

A distribuição espacial das áreas preservadas nesta paisagem permite disseminar alguns valores, como a necessidade de adotar novas estratégias para aumentar as áreas preservadas, e principalmente, respeitar as áreas determinadas das APPs, a fim de se obter a real eficácia da funcionalidade da mesma, aumentando assim a conectividade entre os fragmentos e uma maior proteção às nascentes. Essa análise espacial juntamente com as políticas ambientais é decisiva para estabelecer estratégias para conservar e dinamizar as interações ecológicas e hidrológicas.

Corredores constituem um grau de conectividade estrutural entre os fragmentos, o que representa uma estratégia clara e atingível para o manejo de paisagens fragmentadas, possibilitando a redução da pressão sobre o entorno das áreas. Os fragmentos florestais deveriam ser conectados entre si por meio dos corredores ecológicos, para assim haver uma preservação e manutenção da vida silvestre existente nesses remanescentes, pois a disposição em que os fragmentos e corredores se encontram determina a disponibilidade de recursos para manutenção populacional, funcionando como circulação para toda a biota.

Os pequenos fragmentos desempenham o papel de trampolim ecológico, fazendo as ligações entre essas áreas, grandes e pequenas, promovendo o aumento da circulação da biodiversidade existente nos fragmentos. Por isso os fragmentos com pequenas áreas merecem vigilância, podendo ser extintos a qualquer momento, caso não sejam adotadas políticas de manejo que promovam sua preservação e uma ligação com fragmentos maiores. 


\section{REFERÊNCIAS BIBLIOGRÁFICAS}

AB'SABER, A.N. Regiões de Circundesnudação Pós-Cretáceos no Planalto Brasileiro. Boletim Paulista de Geografia, 1: 3-21, 1949.

ARRUDA, M. B.; NOGUEIRA DE SÁ, L.F.S Corredores Ecológicos: uma abordagem integrada de ecossistemas no Brasil. Ibama: 220, 2004.

BAILEY, S. Increasing connectivity in fragmented landscapes: an investigation of evidence for biodiversity gain in woodlands. Forest Ecology and Management, 238: 7-23, 2007.

BIZINHA, M. G. A importância do Urbanismo e da Paisagem no Desenvolvimento da Estâncias Hidrominerais de Poá, Águas de Lindóia e São Pedro. Dissertação (Mestrado em Arquitetura e Urbanismo) Universidade Presbiteriana Mackenzie - São Paulo, 2013.

BOGAERT, J.; CEULEMANS, R.; SALVADOR-VAN EYSENRODE, D. Decision tree algorithm for detection of spatial processes in landscape transformation. Environmental Management, 33: 62-73, 2004.

CERQUEIRA, R.; BRANT, A.; NASCIMENTO, M. T.; PARDINI, R. Fragmentação: alguns conceitos. In: Rambaldi, D.M.; Oliveira, D.A.S. (Org.). Fragmentação de Ecossistemas: Causas, efeitos sobre a biodiversidade e recomendações de políticas públicas. Brasília: MMA/SBF; cap.01: 24-40, 2003.

CHIARAVALlOtI, R. M.; DELELIS, C.; TOFOLI. C.; PADUAA, C. V.; RIBEIRO, K. T.; MENEZES, G.A. Federal protected areas management strategies in Brazil: sustainable financing, staffing, and local development. Natureza \& Conservação, 13: 30-34, 2015.

COLOMBO, A. F.; JOLY, C.A. Brazilian Atlantic Forest lato sensu: the most ancient Brazilian forest, and a biodiversity hotspot, is highly threatened by climate change. Brazilian Journal of Biology, 70(3): 697-708, 2010.

DAMSCHEN, E. I. Landscape Corridors. Encyclopedia of Biodiversity, 2: 467-475, 2013.

FACINCANI, E. M. Influência da estrutura e tectônica no desenvolvimento das boçorocas da região de São Pedro/SP: proposta de reabilitação e aspectos jurídico institucionais correlatos. Dissertação (Mestrado em Geociências e Meio Ambiente) - Instituto de Geociências e Ciências Exatas, Universidade Estadual Paulista, Rio Claro, 1995.

FOLEY, J. A.; DEFRIES, R.; ASNER, G. P.; BARFORD, C.; BONAN, G.; CARPENTER, S. R.; CHAPIN, F. S.; COE, M. T.; DAILY, G. C.; GIBBS, H. K.; HELKOWSKI, J. H.; HOLLOWAY, T.; HOWARD, E. A.; UCHARIK, C. J.; MONFREDA, C.; PATZ, J. A.; PRENTICE, I. C.; RAMANKUTTY, N.; SNYDER, P. K. Global consequences of land use. Science, 309: 570574, 2005.

FORMAN, R. T. T.; GODRON, M. Landscape Ecology. New York: John Wilwy \& Sons: 619, 1986.

GALETTI, M.; FERNANDEZ, J. C. Palm heart harvesting in the Brazilian Atlantic forest: changes in industry structure and the illegal trade. Journal of Applied Ecology 35: 294301.1998 .

GALINDO-LEAL, C.; CÂMARA, I. G. Mata Attântica: biodiversidade, ameaças e perspectivas. São Paulo: Fundação SOS Mata Atlântica: 3-11, 2005.

GALINDO-LEAL, C.; JACOBSEN, T. R.; LANGHAMMER P. F.; OLIVIERI, S. State of the hot spots: the dynamics of biodiversity loss. Center for Applied Biodiversity Science, pp. 12-23. 2003 
GILBERT-NORTON, W. L. R.; STEVENS, J. R.; BEARD, K. H. A meta-analytic review of corridor effectiveness. Conservation Biology, 24: 660-668, 2010.

GOOSEM, M. Fragmentation impacts caused by roads through rainforests. Current Science, 93: 1587-1595. 2007.

GUIDOS. Disponível no site: http://forest.jrc.ec.europa.eu/biodiversity/GUIDOS.

GUIMARÃES, B. B.; LEAL, A. C. Código Florestal brasileiro: análise do conceito de Área de Preservação Permanente e sua aplicação na bacia hidrográfica do Córrego São Pedro Anhumas, São Paulo. Boletim Campineiro de Geografia, 5(1): 1-17, 2015.

HERNÁNDEZ, A.; MIRANDA, M.; ARELLANO, E. C.; SAURA, S.; OVALLE, C. Landscape dynamics and their effect on the functional connectivity of a Mediterranean landscape in Chile. Ecological Indicators, 48(9): 198-206, 2014.

IBGE - FUNDAÇÃO INSTITUTO BRASILEIRO DE GEOGRAFIA E ESTATÍSTICA. Mapa de vegetação do Brasil. Rio de Janeiro, 1993.

JOLY, C. A; BRITO, M. C. W.; PAESE, A.; METZGER, J. P.; CASATTI, L.; NALON, M. A.; MENEZES, N.; IVANAUSKA, N. M.; BOLZANI, V.; BONONI, V. L. R. Diretrizes para conservação e restauração da biodiversidade no Estado de São Paulo. Governo do Estado de São Paulo: 45-56, 2008.

LAURANCE, W. F.; GOOSEM, M.; LAURANCE, S. G. W. Impacts of roads and linear clearings on tropical forests. Trends in Ecology \& Evolution, 24(12): 659-669, 2009.

LEES, A. C.; Peres, C. A. Conservation value of remnant riparian forest corridors of varying quality for Amazonian birds and mammals. Conservation Biology, 22(2):439-449, 2008.

LIMA, M. G.; GASCON, C. The conservation value of linear forest remnants in central Amazonia. Biological Conservation, 91: 241-247, 1999.

MANO, M. Os campos de Araraquara: um estudo de história indígena no interior paulista / Marcel Mano. Campinas, SP: Tese (doutorado) - Universidade Estadual de Campinas, Instituto de Filosofia e Ciências Humanas, 2006.

MARQUES, A. J. Mapeamento de Fragmentos de Mata no Município de Maringá, PR: Uma abordagem da ecologia da paisagem. Dissertação apresentada ao Programa de PósGraduação em Ciências Cartográficas, Universidade Estadual Paulista, Presidente Prudente, São Paulo, 2004.

MCGARIGAL, K.; CUSHMAN, S. A.; Comparative evaluation of experimental approaches to the study of habitat fragmentation effects. Ecological Applications, 12(2): 335-345, 2002.

McGARIGAL, K.; MARKS, B. J. FRAGSTATS: Spatial Pattern Analysis Program for Quantifying Landscape Structure. General technical report, Fort Collins, 1: 122, 1995.

MENDOZA, E.; FAY, J.; DIRZO, R. A quantitative analysis of forest fragmentation in Los Tuxtlas, southeast Mexico: patterns and implications for conservation. Revista Chilena de História Natural, 78(3): 451-467, 2005.

METZGER, J. P.; BERNACCI, L. C.; GOLDENBERG, R. Pattern of tree species diversity in riparian forest fragments with different widths (SE Brazil). Plant Ecology, 133:135-152, 1997.

MOURA, D. C.; SCHLINDWEIN, C. The gallery forests of the São Francisco river as corridors for euglossine bees (Hymenoptera: Apidae) from tropical rainforests. Neotropical Entomology, 38: 281-284, 2009. 
MURCIA, C. Edge effects in fragmented forests: implications for conservation. Trends in Ecology \& Evolution; 10(2): 58-62, 1995.

MYERS, N. The extinction spasm impending: synergisms at work. Conservation Biology, 1(1): 14-21, 1987.

MYERS, N.; MITTERMEIER, R. A.; MITTERMEIER, C. G.; FONSECA, G. A. B.; KENT, J. Biodiversity hotspots for conservation priorities. Nature, 403:852-858, 2000.

NeTtesheiM, F. C.; MENEZES, L. F. T. DE; CARVALHO, D. C. de; CONDE, M. M. S.; ARAUJO, D. S. D. de. Influence of environmental variation on Atlantic Forest tree-shrub-layer phytogeography in southeast Brazil. Acta Botanica Brasilica, 24(2): 369-377, 2010.

NOWAKOWSKI, A. J.; JIMÉNEZ, M.; ALLEN, B. O.; DIAZ-ESCOBAR, M.; DONNELLY, M. A. Landscape resistance to movement of the poison frog, Oophagapumilio in the lowlands of northeastern Costa Rica. Animal Conservation, 16(2): 188-197, 2012.

OLIFIERS, N.; CERQUEIRA, R. Fragmentação de habitat: efeitos históricos e ecológicos. In: ROCHA, C. F. D.; BERGALlO, H. G.; VAN SLUYS, M.; ALICE, M. A. S. Biologia da Conservação: essências. São Carlos, 2006.

OLIVEIRA-FILHO, A. T.; FONTES, M. A. L. Patterns of Floristic Differentiation among Atlantic Forests in Southeastern Brazil and the Influence of Climate. Biotropica, 32(4b): 793-810, 2000.

PARDINI, R.; SOUZA, S. M. de; BRAGA-NETO, R.; METZGER, J. P. The role of forest structure, fragment size and corridors in maintaining small mammal abundance and diversity in an Atlantic forest landscape. Biological Conservation, 124: 253-266, 2005.

PRIMACK, R. B.; RODRIGUES, E. Biologia da conservação. Londrina: Planta: 37, 2001.

RANTA, P.; BLOM, T.; NIEMELÄ, J.; JOENSUU, E.; SIITONEN, M. The fragmented Atlantic rain forest of Brazil: size, shape and distribution of forest fragments. Biodiversity and Conservation, 7: 385-403, 1998.

REIS, A.; BECHARA, F. C.; ESPÍNDOLA, M. B.; VIEIRA, N. K.; SOUZA, L. L. Restauração de áreas degradadas: a nucleação como base para incrementar os processos sucessionais. Natureza \& Conservação, 1(1): 28-36, 2003.

RIBEIRO, M. C.; METZGER, J. P.; MARTENSEN, A. C.; PONZONI, F. J.; HIROTA, M. M.The Brazilian Atlantic Forest: How much is left, and how is the remaining forest distributed? Implications for conservation. Biological Conservation, 142(6): 1141-1153, 2009.

RICKETTS, T. H. The Matrix Matters: Effective Isolation in Fragmented Landscapes. The American Naturalist 158(1): 87-99, 2001.

RODRIGUES, R. R. Instituto de Pesquisas e Estudos Florestais. ISSN 0100-3453 A vegetação de Piracicaba e municípios do entorno. Nota Técnica NO 189,1999.

ROSS, J. L. S.; MOROZ, I. C. Mapa geomorfológico do estado de São Pulo. 1. São Paulo: Edusp, 1997.

SILVA, W. G. S.; METZGER, J. P.; SIMÕES, S.; SIMONETTI, C.; Relief influence on the spatial distribution of the Atlantic Forest cover at the Ibiúna Plateau, SP. Brazilian Journal of Biology, 67: 403-411, 2007.

TABARELLI, M.; PINTO, L. P.; SILVA, J. M. C.; HIROTA, M.; BEDÊ, L. Challenges and opportunities for biodiversity conservation in the Brazilian Atlantic Forest. Conservation Biology, 19(3): 695-700, 2005. 
TISCHENDORF, L.; FAHRIG, L. On the usage and measurement of landscape connectivity. Oikos 90: 7-19, 2000.

TUBELIS, D. P.; COWLING, A.; DONNELLY, C. Landscape supplementation in adjacent savannas and its implications for the design of corridors for forest birds in the central Cerrado, Brazil. Biological Conservation, 118: 353-364, 2004.

UEZU, A.; METZGER, J. P.; VIELLIARD, J. M. Effects of structural and functional connectivity and patch size on the abundance of seven Atlantic Forest bird species. Biological Conservation, 123:507-519, 2005.

YOUNG, C. E. F. Socieconomic causes of deforestation in the Atlantic forest of Brazil. Center for Applied Biodiversity Science: 103-117. 2003.

VALENTE, R. O. A. Análise da Estrutura da Paisagem na Bacia do Rio Corumbataí, SP. Dissertação (Mestrado em Recursos Florestais). Escola Superior de Agricultura Luiz de Queiroz, Universidade de São Paulo, Piracicaba, 2001.

VANDERMEER, J.; CARVAJAL, R. Metapopulation dynamics and the quality of the matrix. The American Naturalist, 158 (3):211-220, 2001.

VIANA, V. M. Biologia e manejo de fragmentos florestais naturais. In: CONGRESSO FLORESTAL BRASILEIRO, 6, 1990, Campos do Jordão. Anais: Campos do Jordão: SBS/SBEF: 113-118, 1990

VIANA, V. M.; PINHEIRO, L. A. F. V. Conservação da biodiversidade em fragmentos florestais. SÉRIE TÉCNICA IPEF, 12(32): 25-42, 1998.

VOGT P. GUIDOS: tools for the assessment of pattern, connectivity, and fragmentation. Geophysical Research Abstracts, 15, 2013. 